\title{
De Nederlandse revolutie in dorp en stad
}

\author{
Lokale geschiedschrijving over de patriots-Bataafse tijd, 1875 tot heden
}

Joris Oddens

TVGESCH 130 (4): 565-591

DOI: 10.5117/TVGESCH2017.4.ODDE

\begin{abstract}
The Dutch revolution in village and town. Local history-writing on the Patriot-Batavian era, 1875 to the present

The Dutch revolution has been a particularly appealing subject for local historians. Since the last quarter of the nineteenth century, historians have produced numerous studies dealing with the Patriot era (c. 1780-87), the Batavian revolution (c. 1795-1801), or the wider revolutionary era, largely from a local perspective. In this contribution I identify key works, overarching themes, and historiographical trends. I have tried also to consider non-professional historical studies, often written in the context of local history societies and published in local history journals, that rarely attract the interest of academic scholarship. As professional historians have established in smaller-scale comparative studies, the revolution meant different things in different localities, but we lack a coherent picture of what the revolutionary map of the Netherlands looked like and why. The non-professional tradition of local history-writing can help to answer these questions.
\end{abstract}

Keywords: Dutch history, historiography, age of revolution, local history, non-professional history writing 
In 1787 kwam er een abrupt einde aan de patriottentijd. Tweehonderd jaar later, rond het jaar 1987, zagen opmerkelijk veel studies over de revolutionaire patriottenbeweging het licht. ${ }^{1}$ In de collectieve herinnering van de historische gemeenschap in Nederland is ' 1987 ' sindsdien gaan gelden als Stunde Null van een bredere historische belangstelling en waardering voor de twee decennia vanaf het begin van de patriottentijd tot het einde van de revolutionaire fase van de Bataafse republiek. Het jaar 1987 is dit jaar dertig jaar geleden. In die drie decennia is het goed gebruik geworden om zo'n beetje iedere wetenschappelijke bijdrage over het revolutietijdvak te beginnen met de quasi-verontwaardigde vaststelling dat dit tijdvak er in de Nederlandse geschiedschrijving toch zo bekaaid vanaf is gekomen.

Hoewel er uiteraard nog veel werk te doen is, moeten we daar nu maar eens mee ophouden. De dertigste verjaardag van ' 1987 ' lijkt me daarom een mooie aanleiding om inzicht te bieden in juist de rijkdom van de geschiedschrijving over het Nederlandse revolutietijdvak. Ik heb ervoor gekozen om me in dit artikel specifiek te richten op de bestudering van de revolutie binnen de lokale context van

1 Zie voor overzichten van de rond 1987 verschenen publicaties: A.H. Huussen jr., '1787. De Nederlandse revolutie? Recensieartikel', Bijdragen en Mededelingen betreffende de Geschiedenis der Nederlanden (BMGN) 104 (1989) 684-69o; W.Ph. Te Brake, 'Staking a new claim to an old revolution. A review article', Tijdschrift voor Geschiedenis (TvG) 104 (1991) 15-23. Dit artikel werd geschreven in het kader van het NWO-programma The persistence of civic identities in the Netherlands, 1747-1848. Ik dank de redactie en referenten en mijn projectcollega's Carolien Boender, Lauren Lauret, Judith Pollmann, Diederik Smit en Henk te Velde voor hun commentaar. Simone Nieuwenbroek ben ik zeer dankbaar voor haar hulp bij het verkrijgen van de voor dit artikel geraadpleegde literatuur. dorp of stad. Dit perspectief is in eerdere historiografische bijdragen nooit als zodanig aan bod gekomen, terwijl de periode tussen circa 1780 en 1800 juist vaak op deze manier is benaderd. ${ }^{2}$ We beschikken inmiddels over een keur aan waardevolle lokale studies, die echter hoofdzakelijk doorwerken in lokale of soms regionale historiografische debatten. Pogingen om op basis van de lokaalhistorische literatuur tot een synthese te komen zijn er tot nu toe nauwelijks geweest. Een bruikbaar historiografisch overzicht lijkt me hiervoor een eerste noodzakelijke stap. Het voornaamste doel van deze bijdrage is dan ook een impuls te geven aan nationaal-vergelijkend onderzoek naar de $\mathrm{Ne}$ derlandse revolutie op lokaal niveau.

Ik bespreek hier de lange lijn van de lokale revolutiegeschiedschrijving, die loopt van de late negentiende eeuw tot het heden. De lokale geschiedschrijving is bij uitstek het domein van niet-professionele geschiedschrijvers. Hiertoe reken ik heel ruim iedere auteur die op het moment van publicatie niet met een afge-

2 Zie onder voor eerdere historiografische overzichten: E.O.G. Haitsma Mulier, 'De geschiedschrijving over de patriottentijd en de Bataafse tijd', in: W.W. Mijnhardt ed., Kantelend geschiedbeeld. Nederlandse historiografie sinds 1945 (Utrecht etc. 1983) 206-227 en 352-355; N.C.F. van Sas, 'De Nederlandse revolutie van de achttiende eeuw', BMGN 100.4 (1985) 636-646; G.J. Schutte, 'Van verguizing naar eerherstel. Het beeld van de patriotten in de negentiende en twintigste eeuw', in: F. Grijzenhout, W.W. Mijnhardt en N.C.F. van Sas ed., Voor vaderland en vrijheid. De revolutie van de patriotten (Amsterdam 1987) 177-192; Willem Frijhoff en Joost Rosendaal, 'La révolution régénérée. Nouvelles approches et nouvelles images de la Révolution néerlandaise', in: Michel Vovelle ed., L'image de la Révolution française (4 delen, Parijs etc. 1990) I, 543561; Annie Jourdan en Joost Rosendaal, 'Introduction. La Révolution batave à l'entrée du troisième millénaire. Nouveaux problèmes, nouvelles approches, nouveaux objets', Annales Historiques de la Révolution française 73.4 (2001) 2-23. 
ronde opleiding geschiedenis beroepshalve verbonden was aan een universiteit of een onderzoeks- of erfgoedinstelling. Niet-professionele geschiedschrijvers zijn er in soorten en maten, van de afgestudeerde historicus die als onbetaalde buitenpromovendus historisch onderzoek heeft verricht tot de auteur die zonder historische opleiding maar met des te meer enthousiasme heeft bijgedragen aan het tijdschrift van een lokaalhistorische vereniging.

De status van niet-professionele geschiedschrijving is onder vakhistorici ambivalent. Vakhistorici baseren zich als het zo uitkomt graag op de bevindingen van hun niet-professionele collega's. Toch krijgen die relatief zelden een plaats in historiografische overzichten. In het literatuuronderzoek dat ten grondslag ligt aan dit artikel heb ik daarentegen vooraf geen onderscheid willen maken tussen geschiedschrijving in brede zin en geschiedwetenschap. Ik heb breed gezocht naar lokale casestudy's van allerlei aard en herkomst. Deze zoektocht heeft daardoor meer materiaal opgeleverd dan doorgaans in historiografische studies wordt betrokken, veel meer ook dan hier een plaats kan krijgen. Ik probeer het gehele spectrum te overzien en stel met deze brede blik de vraag naar de betekenis van '1987' opnieuw.

\section{Het 'verhaal der feiten' primeert: 1875 tot 1975}

In 1887 , een eeuw na het einde van de patriottentijd, liet de Amsterdamse hoogleraar geschiedenis Th. Jorissen optekenen: 'Misschien zal er in de oude hoofdstad van 't land van Arkel wel iemand lust gevoelen [...] Gorinchem in den patriottentijd ons te teekenen. Het kan een belangrijk verhaal zijn, waarin het aan afwisseling niet zal ontbreken'. ${ }^{3}$ Deze aansporing was op dat moment minder alledaags dan zij nu misschien lijkt. Plaatselijke geschiedschrijving van de revolutie was tot dan toe het domein geweest van biografische studies over vooraanstaande revolutionairen, waarin lokale verwikkelingen een onvermijdelijk deel van de achtergrond vormden. Van de hand van Jorissen, een van de weinige historici die zich vóór Colenbrander diepgaand in het revolutietijdvak verdiepte, was in 1875 De patriotten te Amsterdam in 1794 verschenen. ${ }^{4}$ Jorissen baseerde zich in zijn onderzoek vooral op contemporaine egodocumenten en stelde daarbij één stad centraal. Het ging daarbij niet om zomaar een stad, maar om Amsterdam, waar aan de vooravond van de Bataafse omwenteling de landelijk opererende ondergrondse revolutionaire beweging haar commandocentrum had opgetrokken. Hoewel aan de gebeurtenissen die Jorissen beschrijft dus een nationaal belang was toe te schrijven, toonde hij niettemin hoe lokale geschiedschrijving eruit kon zien: wat hem betreft allereerst als een 'verhaal der feiten'.

3 Theod. Jorissen ed., Memoriën van mr. Diderik van Bleyswijk 1734-1755 (Utrecht 1887) 131.

4 Idem, De patriotten te Amsterdam in 1794 (Amsterdam 1875). Zie over de revolutiegeschiedschrijving vóór Colenbrander: P.B.M. Blaas, 'De patriottenbeweging als epiloog. Rond Colenbranders "Patriottentijd", in: Th.S.M. van der Zee, J.G.M.M. Rosendaal en P.G.M. Thissen ed., 1787. De Nederlandse revolutie? (Amsterdam 1988) 9-26; Wyger R.E. Velema, 'The Dutch, the French and Napoleon. Historiographical reflections on a troubled relationship', in: Antonino di Francesco ed., Da brumaio ai cento giorni. Cultura di governo e dissenso politico nell'Europa di Bonaparte (Milaan 2007) 39-51.

5 Jorissen, De patriotten te Amsterdam, xxii. 


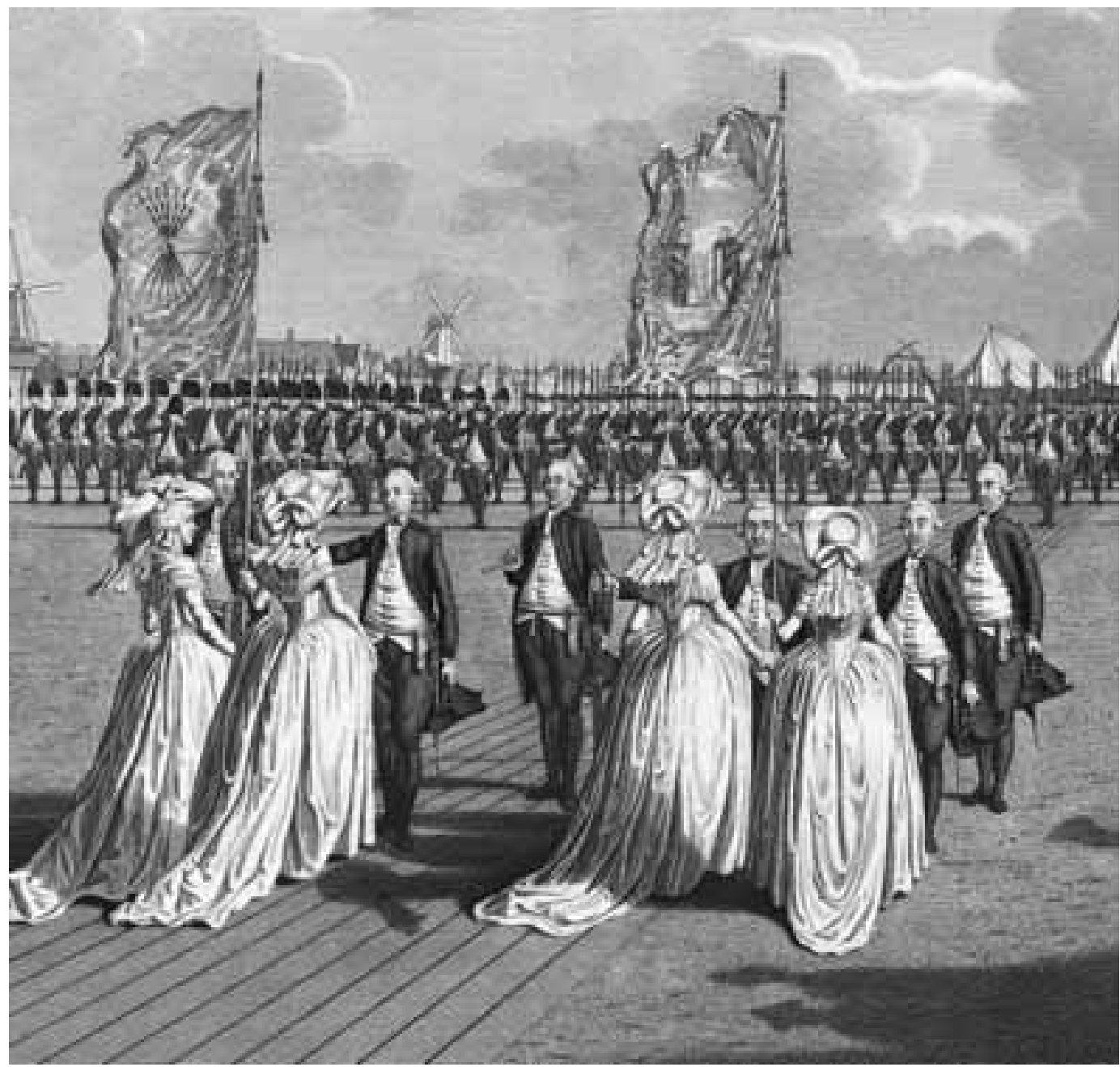

Overdracht van vaandels aan het exercitiegenootschap Tot Nut der Schuttery bij de Buitensingel buiten de Leidsepoort te Amsterdam, 1786 (detail). Prent door Noach van der Meer, 1786.

Rijksmuseum Amsterdam

Voor Jorissen sprak het vanzelf dat lokale geschiedschrijving van de revolutie zou worden geschreven door historici ter plaatse, zoals hij dat voor Amsterdam had gedaan. Dit zouden in de meeste gevallen historici zijn die buiten de wetenschap opereerden. Omdat hij dit type geschiedschrijving zag als een vorm van bronnenontsluiting vond hij dit geen bezwaar. De 'definitieve' oordeelsvorming zou later, wanneer er meer bekend was, moeten volgen. ${ }^{6}$ Nog ietwat weifelend kwam rond deze tijd inderdaad een nieuw historisch genre tot stand: de lokaalhistorische beschrijving van de patriottentijd of de Bataafse revolutie door de historicus die schrijft over zijn eigen woonplaats. In 1886 verscheen een studie over de patriotten in Alkmaar van de hand van C.W. Bruinvis, op dat moment wethouder en

6 Ibidem, xxiii. 
later onbezoldigd gemeentearchivaris van die stad. ${ }^{7}$ Enkele jaren later publiceerde J.F. Croockewit een boekje over de patriottentijd in Wijk bij Duurstede. ${ }^{8}$ Croockewit geniet vooral enige bekendheid als beeldend kunstenaar en de geschiedschrijving lijkt voor hem volstrekte liefhebberij te zijn geweest. Hij vormde daarmee in de decennia rondom de eeuwwisseling een uitzondering, want verder waren het veelal archivarissen, zoals $\mathrm{K}$. Heeringa in Schiedam, J. Smit in Den Haag en J.C. Breen in Amsterdam, die de prille traditie van de lokale revolutiegeschiedschrijving in stand hielden. ${ }^{9}$

Aanvankelijk waren vooral de Hollandse steden onderwerp van studie. In de loop van de vroege twintigste eeuw breidde de belangstelling voor de revolutie op lokaal niveau zich geleidelijk uit. In het jaarboek van de historische vereniging van Overijssel verscheen van de hand van F.A. Hoefer, vrijwillig archivaris te Hattem, reeds in 1896 een bijdrage over het kleine IJsselstadje dat in de patriottentijd landelijk nieuws werd toen het werd aangevallen door de troepen van stadhouder Willem V.$^{10}$ In Gelderland was in 1903 een

7 C.W. Bruinvis, Het patriotisme te Alkmaar (Alkmaar 1886). Later verscheen van dezelfde auteur over Alkmaar nog Politieke afstraffing en zuivering in 17951798. Met een naschrift betreffende 1799 (z.p. 1904).

8 J.F. Croockewit, De patriotten te Wijk-bij-Duurstede, in de jaren 1783-1787 (Wijk bij Duurstede 1889).

9 K. Heeringa, 'Schiedam in den patriottentijd', Bijdragen voor Vaderlandsche Geschiedenis en Oudheidkunde 3 (1903) 376-444; J. Smit, Den Haag in den Franschen tijd. Een drietal schetsen (Den Haag [1913]); idem, Den Haag in den patriottentijd (Den Haag [1916]); J.C. Breen, 'De regering van Amsterdam gedurende den Franschen tijd', Jaarboek Amstelodamum 12 (1914) 1130.

10 A. Hoefer, 'Bijdrage tot de onlusten te Hattem op het einde der vorige eeuw', Verslagen en Mededeelingen van de Vereeniging tot beoefening van Overijsselsch Regt en Geschiedenis 19 (1896) 88-170. academisch proefschrift verschenen over die provincie in de patriottentijd. ${ }^{11}$ Misschien ging de aandacht van de Gelderse archivarissen Van Veen en Van Schilfgaarde daarom niet uit naar de patriotten maar naar het Bataafse tijdvak, en meer in het bijzonder naar die plaatsen die in de tijd van de Republiek de autonome status van vrije heerlijkheid hadden gehad en na 1795 tegen wil en dank door de gewestelijke bestuurders werden ingelijfd. ${ }^{12}$ In 1916 verscheen het artikel 'De omwenteling van 1795 in Stad en Lande' van J.S. Theissen, een gepromoveerd historicus die bibliothecaris zou worden van de Groningse universiteitsbibliotheek. ${ }^{13}$ De dominante positie van de stad Groningen en de weinig ontwikkelde staat van het lokale bestuur in de Ommelanden zou ook latere historici relatief vaak doen besluiten om 'Stad' en 'Lande' samen te behandelen. ${ }^{14}$

De meeste studies die voor de Tweede Wereldoorlog verschenen, zijn beschrijvend van aard en richten zich op de politieke gebeurtenissen in een bepaalde stad, precies zoals Jorissen zich dat voor zich zag. Auteurs baseerden zich hoofdzakelijk op de archieven van het lokale bestuur en op politiek drukwerk. Hun blik bleef door-

11 H.A. Weststrate, Gelderland in den Patriottentijd (Arnhem 1903, dissertatie Utrecht).

12 J.S. van Veen, 'De omwenteling te Culemborg in 1795', Bijdragen en Mededeelingen der Vereeniging "Gelre" 23 (1920) 65-77; A.P. van Schilfgaarde, 'De incorporatie van het graafschap Buren 1795-1814', Bijdragen en Mededeelingen der Vereeniging "Gelre" 38 (1935) 249-275. Beide auteurs waren werkzaam bij het Gelders Rijksarchief.

13 J.S. Theissen, 'De omwenteling van 1795 in Stad en Lande', Historische avonden 3 (1916) 119-162.

14 K. Hildebrand, 'De Patriottenbeweging in Stad en Lande 1780-1787', Groningse Volksalmanak (1950) 1-71; H.A. Kamphuis, Stad en Lande tijdens de Bataafse Republiek. Bestuurlijke en gerechtelijke verhoudingen in Groningen, 1795-1807 (Assen 2005). 
gaans strak gericht op de plaats die zij behandelden. Meestal werd daarbij volstaan met de opmerking dat de revolutie voor desbetreffende stad nog niet beschreven was of werd de onderwerpskeuze in het geheel niet verantwoord. ${ }^{15}$ Slechts een enkele auteur ondernam een serieuze poging om zijn lokale casus door middel van een inleiding in te bedden in bredere nationale en internationale ontwikkelingen. $^{16}$

Een aantal bijdragen onttrekt zich aan dit stramien. 'Rotterdam onder de Bataafsche Republiek' van F.C. Koch, een eigenzinnige vrijwillig medewerker van het Rotterdamse archief, verscheen tussen 1927 en 1948 in afleveringen in het Rotterdamsch Jaarboekje en beslaat in totaal ruim zevenhonderd pagina's. Alleen in omvang al wijkt deze studie daarmee sterk af van alles wat verder in de vroege twintigste eeuw is verschenen. Behalve de gebruikelijke evenementiële weergave bevatten Kochs levendige artikelen, die geen voetnoten kennen, tal van thematische secties over onderwerpen als sociëteiten, feesten, censuur en inkwartiering. Zo zeldzaam als de brede blik van Koch waren voor de oorlog ook studies die zich juist richtten op één deelaspect van de lokale revolutiegeschiedenis. Een uitzondering vormt een kort artikel uit 1904 van de Haarlemse bibliothecaris W.P.J. Overmeer, die zich boog over de vraag welk aandeel Haarlemse vrouwen in de Ba-

15 Zie bijvoorbeeld W.P.J. Overmeer, De omwenteling in 1795 te Haarlem en omstreken (Haarlem 1905) 3. 16 Zie bijvoorbeeld W.J. Formsma, 'De revolutie van 1795 in Ootmarsum', Verslagen en Mededeelingen van de Vereeniging tot beoefening van Overijsselsch Regt en Geschiedenis 54 (1938) 137-148. taafse omwenteling hadden gehad. ${ }^{17}$ Een dergelijke meer probleemgestuurde benadering zou pas in de tweede helft van de eeuw algemener worden. De plaats van de vrouw in de revolutie op lokaal niveau zou daarbij overigens altijd onderbelicht blijven. Een van de redenen hiervoor is ongetwijfeld dat de lokale geschiedschrijving van het revolutietijdvak, in tegenstelling tot de revolutiegeschiedschrijving in bredere zin, altijd een mannenaangelegenheid is gebleven. Grote uitzondering in de eerste helft van de twintigste eeuw is De Patriotten te Gouda van M.A.C.M. (Margaretha) van Hattum, de Goudse gemeentearchivaris. Dit is tegelijkertijd het enige vooroorlogse proefschrift over het revolutietijdvak gericht op een enkele stad. $^{18}$

Voorlopig werd er ook nog weinig gehoor gegeven aan de jurist en rechtshistoricus A.S. de Blécourt. Deze pionier op het terrein van de staatkundige geschiedenis van plattelandsgemeenten rond 1800 had al aan het begin van de twintigste eeuw geschreven:

Het ware te wenschen, dat er [...] ontwikkelingsgeschiedenissen van afzonderlijke gemeenten uit alle oorden des lands voorhanden waren, met name van het platteland. [...] Mogen er burgemeesters, secretarissen of archivarissen gevonden worden, die zich hiertoe aangorden en de resultaten van hun arbeid publiceerden. ${ }^{19}$

17 W.P.J. Overmeer, 'Het aandeel der vrouwen aan de omwenteling van 1795 te Haarlem', De Navorscher 54 (1904) 356-364.

18 M.A.C.M. van Hattum, De patriotten te Gouda (Purmerend 1934, dissertatie Leiden).

19 A.S. de Blécourt, De organisatie der gemeenten gedurende de jaren 1795-1851 (Haarlem 1903) 5-6. Mijn cursivering. 
In 1929 vormde toch eens een plattelandsgemeente het onderwerp in West-Friesland's "Oud en Nieuw", een van de eerste periodieken van een niet-grootstedelijke of provinciale historische vereniging. De auteur S. Buisman leidde zijn artikel wel op apologetische wijze in. Hij stelde dat 'ook hier op het platteland eene buitengewone politieke levendigheid' heerste, maar voegde daaraan toe ook wel te weten dat de politieke twisten in de dorpen 'natuurlijk [...] slechts kleinigheden, nietigheidjes, huiselijke twisten' waren. ${ }^{20} \mathrm{Hij}$ koos voor de strategie om de gebeurtenissen in het kleine West-Friese dorp Wervershoof - want daarover ging zijn studie - niet te presenteren als singulier maar als representatief voor het platteland en zo zijn onderwerpkeuze te rechtvaardigen. ${ }^{21}$ Pas vlak na de Tweede Wereldoorlog publiceerde de gepensioneerde gemeentesecretaris J. de Graaf, die had vastgesteld dat De Blécourts wens nog niet in vervulling was gegaan, met volle overtuiging een geschiedenis van het Gelderse dorp Brummen 'in den tijd van overgang'. ${ }^{22}$

$\mathrm{Al}$ in 1883 had de hierboven genoemde Jorissen met een essay de aanduiding 'Franse tijd' ingang doen vinden als benaming van de gehele periode van de Franse inval in 1795 tot het vertrek van Napoleon in 1813. Bij Jorissen kleefde aan deze aanduiding een negatieve connotatie. Hij zag deze periode als 'een tijdperk van volko-

20 S. Buisman, 'Een Noord-Hollandsche gemeente onder de Bataafse Republiek', West-Friesland's "oud en nieuw" 3 (1929) 123-134.

21 Zie voor een ander voorbeeld van deze strategie: Geert Last, Een dorp in de Franse tijd. Het wel en wee van een Groninger gemeenschap tijdens de Napoleontische overheersing (1795-1813) (Noordbroek 1964).

22 J. De Graaf, Brummen in den tijd van overgang (Zutphen 1947). men ondergeschiktheid aan een vreemde mogendheid'. ${ }^{23}$ Pas wanneer we naar de revolutiegeschiedschrijving kijken met een brede blik die zich niet uitsluitend richt op de professionele geschiedwetenschap, blijkt dat afgaand op het gebruik van de aanduiding 'Franse tijd' in publicatietitels deze zienswijze het meest wijdverbreid was in de eerste decennia na de Duitse bezetting. ${ }^{24}$ Studies die de gehele periode 1795-1813 besloegen en deze behandelden als een lange fase van Franse bezetting waren vooral afkomstig van een groep auteurs die vanaf de jaren vijftig definitief haar opwachting maakte: de historisch geïnteresseerden die, vaak als actief lid van een lokaalhistorische vereniging, de geschiedenis schreven van de kleinere gemeenten waar zij (in de buurt) woonden. Typerend voor zulke bijdragen was dat zij een afwisseling boden van lokale gebeurtenissen, vaak grotendeels gebaseerd op de notulen van het plaatselijk bestuur, en gebeurtenissen op nationaal niveau.

Niet door alle auteurs werd het BataafsFranse tijdvak neergezet als een tijd van bezetting. Direct in de eerste zinnen van zijn dissertatie 's-Hertogenbosch in de $\mathrm{Ba}$ taafse en Franse tijd, 1794-1814 (1955) noemde H.F.J.M. van den Eerenbeemt 'de doorbraak van allerlei nieuwe ideeën' het

23 Theod. Jorissen, 'De Fransche tijd' [1883], in: idem, Historische bladen (Haarlem 1889) 333-425; Johan Joor, De adelaar en het lam. Onrust, opruiing en onwilligheid in Nederland ten tijde van het Koninkrijk Holland en de inlijving bij het Franse keizerrijk (1806-1813) (Amsterdam 2000) 29.

24 Zie bijvoorbeeld J. Uitentuis, Huizum in de Franse tijd (z.p. 1950); G. van Duinen, Heemstede in de Franse tijd (Heemstede 1956); H. Dirven, 'Hage in de Franse tijd of: de geschiedenis van Princenhage en Prinsenbeek van 1793-1815', Hage 11 (1974) 5-79; R. Kampman, 'Berichten uit de Franse tijd (Almelo tijdens de "Bataafse Republiek”, 1795-1806)', Jaarboek Twente 14 (1975) 36-52. 
'voornaamste kenmerk' van dit tijdperk; het was in zijn visie het 'baanbrekend werk' uit deze periode dat het koninkrijk van Willem I mogelijk maakte. ${ }^{25}$ Het was geen toeval dat het ging om een studie van een Brabantse stad, geschreven door een Brabander. In Brabant, dat in 1795 transformeerde van Generaliteitsland tot volwaardig gewest, stond de Bataafse omwenteling al langer in een gunstiger licht dan in de rest van Nederland. In navolging van zijn promotor L.G.J. Verberne waardeerde Van den Eerenbeemt het revolutietijdvak niet alleen anders dan op dat moment gebruikelijk was, maar week hij ook af van de heersende evenementiële traditie binnen de revolutiegeschiedschrijving. ${ }^{26}$ Wat Van den Eerenbeemt voor ogen had was een 'sociologische en sociografische ontleding van een stedelijke samenleving in het verleden'. ${ }^{27}$ Dit resulteerde in een situatieschets van Den Bosch in de achttiende eeuw op allerlei sociale en economische terreinen - bevolkingsstructuur, gilden, armenzorg, medische zorg, handel, nijverheid - en een beschrijving van de gevolgen van de ingrijpende maatregelen die in de Bataafs-Franse tijd op deze vlakken werden genomen.

Het eerste naoorlogse lokaalhistorische proefschrift over de patriottentijd verscheen in $195^{\circ}$ en was geschreven door I. Vijlbrief. Het ging volgens de ondertitel om Een bijdrage tot de politieke en sociale geschiedenis der stad Utrecht. De flaptekst

25 H.F.J.M. van den Eerenbeemt, 's-Hertogenbosch in de Bataafse en Franse tijd, 1794-1814. Bijdrage tot de kennis van de sociaal-economische structuur (Nijmegen [etc.] 1955, dissertatie Nijmegen) ix.

26 Verberne hield bij zijn inhuldiging als hoogleraar in Tilburg de oratie Het sociale en economische motief in de Bataafse tijd (Tilburg 1947). Van den Eerenbeemt zou hem later daar opvolgen.

27 Van den Eerenbeemt, 's-Hertogenbosch, ix. verraadde dat de strekking van het boek verder reikte 'dan de enge grenzen ener stadsgeschiedenis zouden doen vermoeden'. ${ }^{28}$ Net als zijn promotor Jan Romein was Vijlbrief erop uit de patriotten de historiografische waardering te geven 'die hun toekwam' door ze neer te zetten als grondleggers van de moderne democratie in Nederland. ${ }^{29}$ De voortrekkersrol die Utrechtse patriotten vertolkten binnen de 'democratisch Patriotse beweging' verklaarde Vijlbrief door te wijzen op de eeuwenlange traditie van anti-aristocratisch verzet die de bisschopsstad zou hebben gekend. Dit verklaringsschema leverde een studie op die voor meer dan de helft bestond uit voorgeschiedenis. Samen met A. van Hulzen, een docent van de Utrechtse Rijkskweekschool die zich in Utrecht in de patriottentijd (1966) meer traditioneel-beschrijvend baseerde op de notulen van het stadsbestuur, zorgde hij er niettemin al vroeg voor dat de Utrechtse patriottenbeweging ging behoren tot de best onderzochte. ${ }^{30}$

In de decennia die volgden, kregen ook kleinere plaatsen als Edam, Tilburg en Nijmegen hun eigen studie over de plaatselijke patriotten, veelal van de hand van niet-professionele historici. ${ }^{31}$ Terwijl historici van de grote greep als R.R. Palmer, C.H.E. de Wit en Simon Schama de patriottenbewe-

28 I. Vijlbrief, Van anti-aristocratie tot democratie. Een bijdrage tot de politieke en sociale geschiedenis der stad Utrecht (Amsterdam 1950, dissertatie G.U. Amsterdam);

29 Ibidem, 283.

30 A. van Hulzen, Utrecht in de patriottentijd (Zaltbommel 1966).

31 P. Smit, Edam in de patriottentijd (z.p. 1964); C.J. Weijters, 'Tilburg in de patriottentijd (1785-1794)', De Lindeboom 1 (1977) 61-89; A.G. Poelen, Saevis tranquillus in undis: stil, tusschen de onstuijmige Zee baaren. Nijmegen en de patriottenbeweging, 1780-1787 (Nijmegen 1979). 
ging en de Bataafse revolutie gingen beschouwen als manifestaties van een grotere, zelfs internationale democratiseringstendens, werd op lokaalhistorisch niveau voorlopig niet afgeweken van de gewoonte om de jaren '80-'87 en '95-'01 als aparte tijdvakken te behandelen. Wel namen enkele auteurs vanaf de jaren zestig het repressieve klimaat in de tussenliggende fase van stadhouderlijke restauratie tot onderwerp. ${ }^{32} \mathrm{Zij}$ gingen als vanzelf ook nadenken over de relatie tussen de eerste en tweede fase van de Nederlandse revolutie. In een artikel uit 1975 over de restauratiejaren in Haarlem kwalificeerde R. Daalder beide fases als 'een verzameling lokale revoluties'. Daalder stelde dat elke stad een 'betrekkelijk autonome ontwikkeling' doormaakte die weliswaar beïnvloed werd door gewestelijke en landelijke verhoudingen en gebeurtenissen maar toch ook zijn eigen lokale dynamiek behield. ${ }^{33}$ Van deze vaststelling naar een langetermijnbenadering was het nog maar een kleine stap.

\section{Verwetenschappelijking, regionalise- ring en de lange termijn: 1975 tot 1990}

In 1980 en 1981 publiceerde het Tijdschrift voor Sociale Geschiedenis in twee delen het artikel 'Het lagere volk van Amsterdam in de strijd tussen patriotten en oranjegezinden, 1780-180o' van I.J. van Manen en K. Vermeulen. ${ }^{34}$ Deze bewerking van

32 Th.N. Eijsink, Restauratie en revolutie in Arnhem, 1 juli 1787-6 mei 1795 ([Arnhem] 1967); R. Daalder, 'Haarlem en de Democratische Revolutie. Haarlem van Patriottentijd tot Bataafse Revolutie (1787-1795)', jaarboek Haerlem (1975) 129-229.

33 Daalder, 'Haarlem', 132.

34 I.J. van Manen en K. Vermeulen, 'Het lagere volk van Amsterdam in de strijd tussen patriotten en oranjegezinden: 1780-180o', Tijdschrift voor Sociale Geschiedenis 30 (1980) 332-356 en 31 (1981) 3-42. een aan de Universiteit van Amsterdam eveneens in duo geschreven doctoraalscriptie uit 1976 is vermoedelijk de eerste lokaalhistorische studie waarin het revolutietijdvak in zijn geheel werd bekeken. De auteurs waren geïnspireerd door het onderzoek van George Rudé naar de crowd in history en hadden diens methode van het verzamelen van gegevens over de deelnemers aan massale samenkomsten in een werkgroep al toegepast op het jaar $1787 .{ }^{35}$ Op basis hiervan hadden zij geconcludeerd dat de sociale samenstelling van de patriotten en de orangisten niet veel van elkaar verschilde. In dit artikel testten zij deze hypothese voor de twee revolutionaire decennia, ditmaal vooral aan de hand van confessieboeken, en kwamen zij tot de vernieuwende conclusie dat 'de scheidslijn die Oranjegezinden en Patriotten verdeelde $[\ldots]$ vertikaal door de samenleving' liep. ${ }^{36}$ Het artikel van Van Manen en Vermeulen werd een belangrijk referentiepunt voor sociaal stratificatieonderzoek naar de strijdende partijen. ${ }^{37}$

Ook door aan de revolutie op lokaal

35 Idzard van Manen (rapporteur), 'De "Crowd" in de Geschiedenis van Amsterdam, de jaren 1696, 1748 en 1787', Mededelingenblad. Orgaan van de Nederlandse Vereniging tot Beoefening van de Sociale Geschiedenis 46 (1974) 43-74.

36 Van Manen en Vermeulen, 'Het lagere volk', II, 35. 37 Zie bijvoorbeeld F.J. Bos en K.H. Rademaker, 'Oranjerellen en vrijkorpsen in de residentie 1782 1787', Leidschrift 4.1 (1987) 86-111; J.R. Kuiper, 'Burgers in beweging. Een onderzoek naar de aard, omvang en samenstelling van de patriottenbeweging te Leeuwarden gedurende de periode 1780-1787', Leidschrift 4.1 (1987) 4-28; M. de Grood, 'Profiel van een oppositie. Sociale gelaagdheid van de Tielse patriottenbeweging', De Drie Steden 8.3 (1987) 43-47; Remco Visschers, 'Patriotten in de graafschap Zutphen. De sociale en religieuze samenstelling van de patriottenbeweging in Doetinchem, Groenlo, Lochem en Doesburg, 17831787', Bijdragen en Mededelingen. Historisch Jaarboek Gelderland 96 (2005) 113-145. 
niveau hun scriptie te wijden, hebben deze auteurs aan de basis gestaan van een trend. Vóór 1980 werd slechts één andere doctoraalscriptie op dit terrein aangetroffen. ${ }^{38}$ Tussen 1980 en 1990 zijn dit er al elf. ${ }^{39}$ Hogere studentenaantallen en betere ontsluiting van scripties hebben hierbij zeker meegespeeld. Niettemin lijkt de conclusie gerechtvaardigd dat een proces van 'eerherstel' voor de patriotten en een sterke belangstelling voor lokale en regionale geschiedenis in de jaren tachtig samenkwamen en dat de lokale revolutiegeschiedschrijving aan de universiteiten nooit populairder is geweest dan in dit decennium. ${ }^{40}$ De meeste scripties bestu-

38 C.A. van Kalveen, 'Amersfoort tijdens de patriottenbeweging' (doctoraalscriptie Utrecht 1961).

39 Ch.C.M. de Mooij, Over aristocraten, Keezen en preekstoels klimmers. Voorgeschiedenis en totstandbrenging van de omwenteling van 1795 te Bergen op Zoom (Tilburg 1981, oorspr. doctoraalscriptie Utrecht); C.A. de Leeuw, 'De patriottenbeweging in 's-Hertogenbosch' (doctoraalscriptie Utrecht 1982); L. Schmitz, 'Een democratisch experiment. Wijk bij Duurstede 1795-1798' (doctoraalscriptie Utrecht 1983); Henk Saaltink, 'Supplianten en requestranten. Achtergronden van de Hoornse partijstrijd 1785-1787' (doctoraalscriptie Rotterdam 1983); T.J. de Bruijn, 'Dordrecht in de patriottentijd. De ambtsverdeling en politieke ontwikkelingen in een stad in de jaren 1780-1788' (doctoraalscriptie Leiden 1984); H. ter Laak, 'De patriotten te Wijk bij Duurstede 1783-1787' (doctoraalscriptie Utrecht 1986); W.A. Knoops, 'De Patriottische Sociëteit in Gouda 1785-1787. Een maatschappelijke en politieke plaatsbepaling' (doctoraalscriptie Leiden 1986); J.R. Kuiper, 'Tussen revolutie en reactie. De politieke elite van Leeuwarden in de jaren 1795-1798' (doctoraalscriptie Groningen 1986); D. Aten, 'De Patriottentijd en Bataafs-Franse tijd op dorpsniveau. De Rijp in de jaren 1780-1813' (doctoraalscriptie UvA 1987); C.H.J. Peters, 'Vlissingen in de patriottentijd, 1780-1787' (doctoraalscriptie Utrecht 1988); R. van der Woude, 'Gelijkheid op krukken. De Bataafse revolutie in de stad Groningen, 1795-1803' (doctoraalscriptie Groningen 1989).

40 Schutte, 'Van verguizing naar eerherstel'; G. Trienekens, 'Theoretische en methodologische aspecten van de lokale en regionale geschiedenis', in: F. van deerden steden gedurende de patriottentijd of de Bataafse revolutie en kozen daarmee voor een beproefd concept. Een uitzondering vormde de scriptie van Diederik Aten die - net als eerder Van Manen en Vermeulen onder begeleiding van E.O.G. Haitsma Mulier - keek naar het Noord-Hollandse dorp De Rijp tussen 1780 en 1813 .

Binnen de ruimtebeperkingen waarmee de scriptie net als het artikel nu eenmaal te maken heeft, is een langeretermijnbenadering van de revolutie ook wel veel gevraagd, tenzij wordt uitgegaan van een zeer gerichte onderzoeksvraag. Voor studies met een bredere insteek lijkt de monografie als medium geschikter. Een geslaagd voorbeeld van zo'n studie is Keeshonden en Prinsmannen. Durgerdam, Ransdorp en Holisloot 1780-1813 van Tom Nieuwenhuis. ${ }^{41}$ In dit in 1986 aan de Universiteit van Amsterdam verdedigde proefschrift over drie dorpen ten noorden van Amsterdam, verenigde Nieuwenhuis historisch bronnenonderzoek met een holistische antropologische blik op de dorpsgemeenschap. Net als Van Manen en Vermeulen was hij geïnteresseerd in de sociale samenstelling van de verschillende strijdende partijen en de motieven van partijaanhangers, maar hij richtte zich ook op de vraag naar de verhouding tussen de lokale en de landelijke revolutionaire beweging. Omdat hij daarbij vergelijkend te werk ging en nauwkeurig inging op de uitgangssituaties van de door hem bestudeerde dorpen slaagde Nieuwenhuis

Besouw e.a. ed., Balans en perspectief. Visies op de geschiedwetenschap in Nederland (Groningen 1987) 167-187.

41 Tom Nieuwenhuis, Keeshonden en Prinsmannen. Durgerdam, Ransdorp en Holisloot: Drie waterlandse dorpen in de Patriottentijd en de Bataafs-Franse tijd (Amsterdam 1986, dissertatie UvA). 


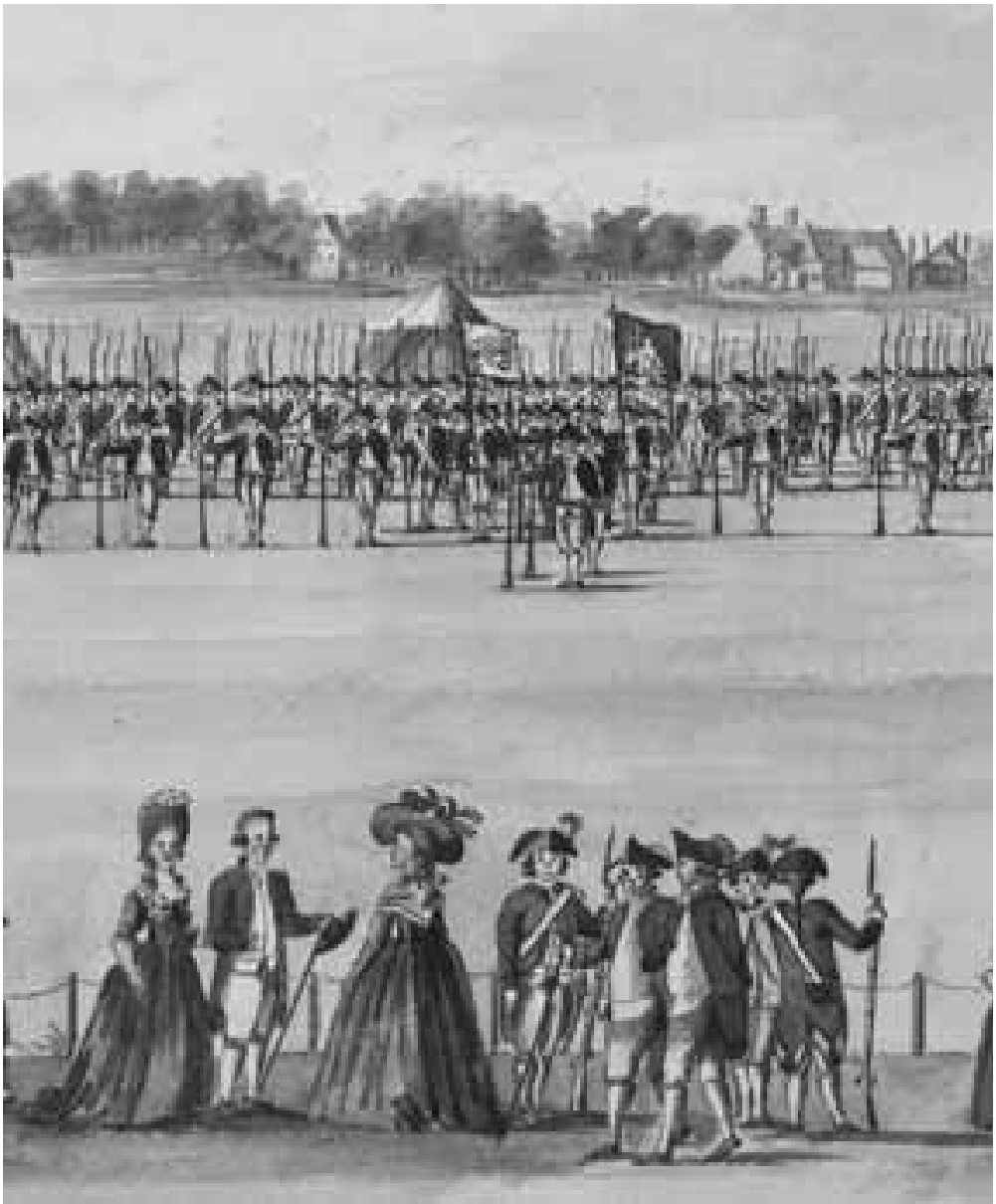

Oefening van de burgerwacht op een veld buiten Leiden (detail). Tekening door Jacob Timmermans, ca. 1787 .

Erfgoed Leiden en omstreken

erin om vat te krijgen op het verschijnsel dat lokale gemeenschappen die zich in elkaars geografische nabijheid bevonden qua dominante politieke voorkeur vaak mijlenver uit elkaar lagen. Zo kon in zijn casus de uitgesproken patriotse hervormingsgezindheid van de inwoners van Durgerdam worden verklaard uit de ondergeschikte positie van dit dorp ten opzichte van Ransdorp binnen de gelijknamige banne. De Ransdorpers streden om dezelfde redenen juist voor behoud voor de status quo en verzetten zich in 1795 tegen de van hogerhand opgelegde gelijke status van beide dorpen. Toen in 1798 de centrale overheid de lokale autonomie inperkte en de Durgerdammers veel van hun net verkregen zelfstandigheid weer moesten inleveren, was het revolutionaire vuur bij hen ook rap gedoofd.

Eveneens van belang is de studie van G.J. Schutte over vier dorpen die behoren tot Graft, een andere Noord-Hollandse banne. Zijn boek met als ondertitel Een Hollandse dorpssamenleving in de late achttiende eeuw (1989) gaat over het tijdvak tussen 1770 en 1810 en geeft een goede 
indruk van de dorpse bestuurspraktijk in de laatachttiende-eeuwse Republiek en de effecten van de (Bataafse) revolutie hierop. Schutte zag overwegend integere bestuurders die de steun genoten van de lokale bevolking en na de Bataafse omwenteling enkele voorheen uitgesloten katholieken en doopsgezinden in hun gelederen toestonden, maar het meeste bij het oude lieten en intussen zo goed en kwaad als het ging probeerden om te gaan met de steeds toenemende hoeveelheid directieven van hogere bestuursniveaus. ${ }^{42}$

Vernieuwend op een andere manier dan deze langetermijnstudies was een initiatief van M.A.M. Franken en R.M. Kemperink, docenten bij de lerarenopleiding in Zwolle, die sinds midden jaren zeventig scriptanten hadden aangespoord zich te richten op de patriottentijd in Overijssel. Dit resulteerde in 1984 in de publicatie van een speciaal nummer van Overijsselse Historische Bijdragen waarvoor tien scripties over de patriotten in diverse Overijsselse steden waren omgewerkt tot artikelen. ${ }^{43}$ Een belangrijk doel van de initiatiefnemers was een aanvulling te bieden op de door hen niet zonder grond als hollandocentristisch ervaren geschiedschrijving van dat moment. De scriptanten hadden opdracht gekregen hun analyse te betrekken op het verloop en het karakter van de

42 G.J. Schutte, Een Hollandse dorpssamenleving in de late achttiende eeuw. De banne Graft 1770-1810 (Franeker 1989).

43 M.A.M. Franken en R.M. Kemperink ed., 'Herstel, hervorming of behoud? Tien Overijsselse steden in de Patriottentijd, 1780-1787', [themanummer] Overijsselse Historische Bijdragen 99 (1984), met bijdragen over Deventer (J. Zandstra), Zwolle (P.J. Lettinga), Kampen (M. van Dam), Oldenzaal (G.J. Hebben), Almelo (R.M. Kemperink op basis van scriptie J.J. Abbes), Ootmarsum (P.H.L. Spee), Hardenberg (H.G. Hoffmann), Vollenhove (G. Winter), Steenwijk (W. Logtmeijer) en Hasselt (F.W. Schmidt). gebeurtenissen en de aard en samenstelling van de patriottenbeweging ter plaatse. ${ }^{44}$ Deze gezamenlijke uitgangspunten stelden Franken in staat om de verschillende steden en stadjes in een slotbeschouwing met elkaar te vergelijken en bijvoorbeeld te verklaren waarom de tegenstellingen onder de bevolking van Ootmarsum en Almelo veel groter waren dan in Oldenzaal en Hardenberg.

De patriottentijd op lokaal niveau was daarmee voorlopig het meest systematisch bestudeerd voor Overijssel. Toch kwam daar vijf jaar later nog de monografie bij van de Amerikaanse historicus Wayne Ph. te Brake. Regents and rebels. The revolutionary world of an eighteenthcentury Dutch city was een bewerking van een twaalf jaar eerder al verschenen proefschrift. Terwijl daarin de interactie tussen stad en platteland meer centraal had gestaan, ging dit boek hoofdzakelijk over de patriottenbeweging in de stad Deventer en in mindere mate over die in Kampen en Zwolle. ${ }^{45}$ Te Brake beschouwde zich als een sociaal historicus en zag het in navolging van zijn leermeester Charles Tilly als de opdracht van sociale geschiedenis om inzicht te bieden in de wijze waarop gewone mensen grote structurele veranderingen zoals de vorming van natiestaten beleefden; een lokaalhistorisch perspectief lag daarbij voor de hand. Net als Tilly had Te Brake daarbij ook veel aandacht voor collectieve actiemiddelen. Door te kijken naar de veranderende samenstel-

44 Franken en Kemperink, 'Inleiding'.

45 W.Ph. Te Brake, Regents and rebels. The revolutionary world of an eighteenth-century Dutch city (Oxford 1989). Later volgde over Deventer in de patriottentijd nog een reeks studies van C.M. Hogenstijn, waaronder de vuistdikke Nijmeegse dissertatie Het algemeen welzijn van het volk. Een politiek- en rechtshistorische studie van Deventer in de Patriottentijd (Nijmegen 2005). 


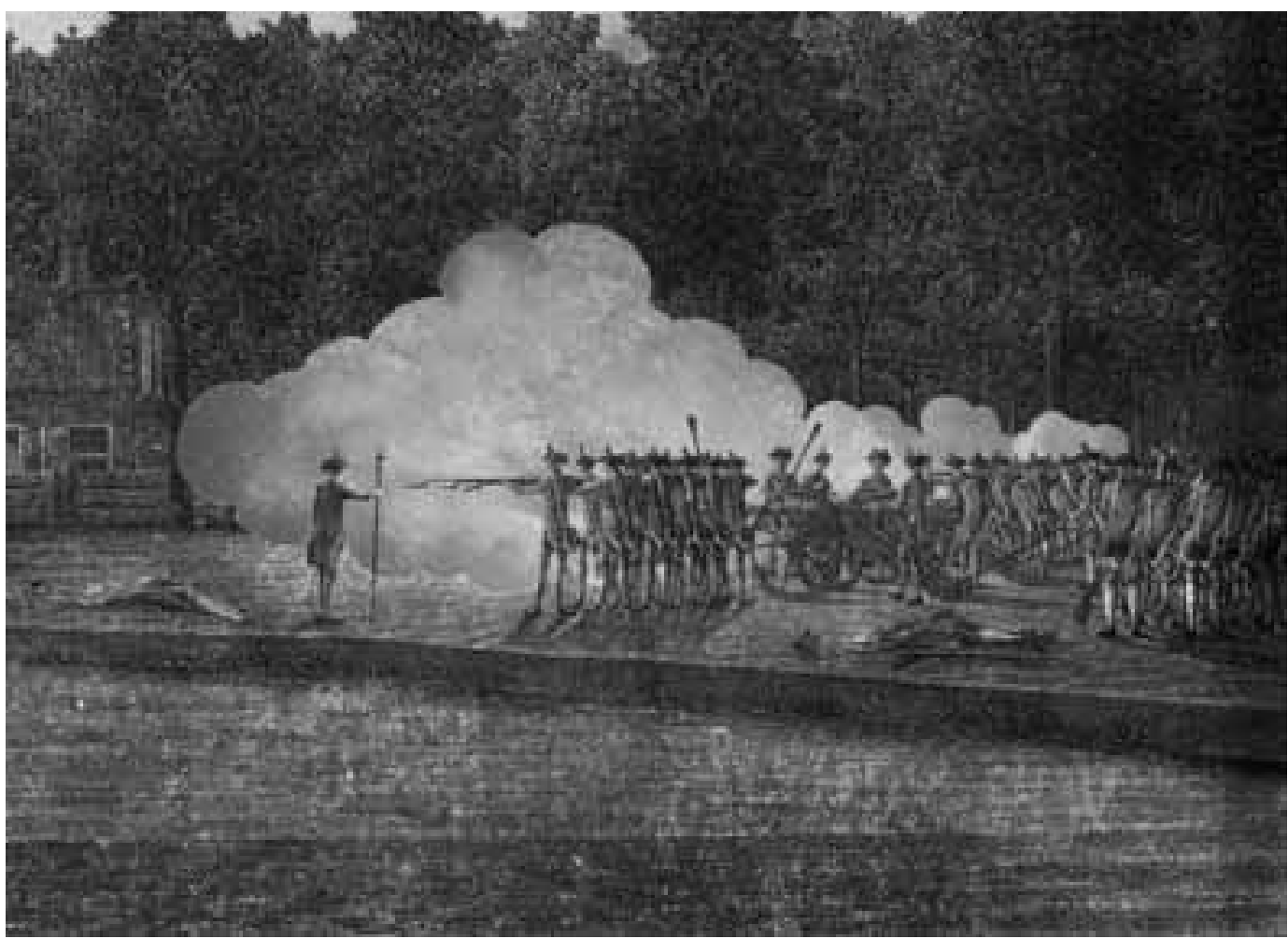

Vuurgevecht aan de Vaartse Rijn bij Jutphaas in 1787 (detail). Glasschildering door Jonas Zeuner, 1787-1788.

Rijksmuseum Amsterdam

ling van de groepen die bij petities en burgermilities betrokken waren, kon hij laten zien dat de Zwolse patriottenbeweging aanvankelijk vooral werd gedragen door de gildes, maar dat veel gildebroeders zich juist tegen de revolutie keerden toen bleek dat het nieuwe patriotse establishment dat zij mede in het zadel hadden geholpen de privileges van de gilden juist wilde inperken.

In een voorwoord op Te Brakes studie uit 1989 plaatst Tilly deze tegen de achtergrond van de hausse aan publicaties die rondom dat jaar verschenen ter gelegenheid van de bicentenaire van de Franse revolutie. Het is goed dat Te Brakes studie er nu ten minste is, luidt de strekking van dit voorwoord, want in vergelijking met het Franse geweld is het tweede eeuwfeest van de patriottenbeweging vrijwel ongemerkt voorbij gegaan. ${ }^{46}$ Deze merkwaardige misvatting zou worden rechtgezet door Te Brake zelf toen hij twee jaar later in dit tijdschrift een historiografisch overzicht gaf van de talrijke publicaties die '1987' had opgeleverd. Het viel hem destijds al op dat, behalve enkele vooral door vakhistorici geschreven, thematische bundels over de patriottentijd, het leeuwendeel van de herdenkingsliteratuur bestond uit 'local or regional studies, often by amateur and apprentice historians' ${ }^{4}{ }^{4}$ Het voorbeeld van Overijssel enkele jaren

46 Te Brake, Regents and rebels, $\mathrm{x}$.

47 Idem, 'Staking a new claim', 16. 
eerder had verschillende anderen op het idee gebracht van gewestelijke studies over de patriottentijd. Het Jaarboek OudUtrecht en het tijdschrift Holland kwamen met themanummers en ook de Historische Vereniging Brabant en de Fryske Akademy zorgden voor een herdenkingsbundel. ${ }^{48}$

Alleen de Brabantse bundel bestond net als zijn Overijsselse pendant overwegend uit lokale casestudy's. Uit de juxtapositie blijkt ook hier hoezeer in het Generaliteitsland Staats-Brabant sprake was van variatie binnen de regio. De Friese bundel was helemaal thematisch georganiseerd, maar de Utrechtse en Hollandse initiatieven boden naast thematische artikelen ook ruimte aan lokaalhistorische bijdragen. In de gezamenlijke presentatie van deze lokale studies kwamen verschillende tendensen uit de voorgaande decennia voor het eerst samen: vakhistorici stonden er tussen gevorderde studenten en leden van lokaalhistorische verenigingen; artikelen over de erkende patriotse bolwerken Leiden en Utrecht werden afgewisseld met bijdragen over dorpen als Maasland en Maarssen; en analytische be-

48 O vrijheid! Onwaardeerbaar pand! Aspecten van de patriottenbeweging in stad en gewest Utrecht, [themanummer] Jaarboek Oud-Utrecht (1987), met lokaalhistorische bijdragen over Utrecht (N.C.F. van Sas), Amersfoort (C.A. van Kalveen), Maarssen en Maarssenveen (J. Uppelschoten) en Vianen (H.J. Smit); 'Holland en de revolutie van 1787', [themanummer] Holland 19.4/5 (1987), met lokaalhistorische bijdragen over Leiden (R.C.J. van Maanen) en Maasland (D.J. Noordam); G.W.J. Rooijakkers, A.M.D. van der Veen en C.J.M. Free ed., Voor 'Brabants Vryheyd'. Patriotten in Staats-Brabant (Den Bosch 1988), met lokaalhistorische bijdragen over Bergen op Zoom (Ch.C.M. de Mooij), Waalwijk (J.G.M.M. Rosendaal), Tilburg (G.J.W. Steijns), 's-Hertogenbosch (C.J.M. Free) en Helmond (M.G.P.M. Jacobs); W. Bergsma e.a. ed., For uwz lân, wyv en bern. De patriottentijd in Friesland (Leeuwarden 1987). naderingen kregen er een plaats naast meer traditioneel-beschrijvende casestudy's.

Het laatste illustreert dat er geen sprake was van een lineaire beweging van beschrijving naar analyse. Weliswaar werd de revolutie op lokaal niveau vanaf de vroege jaren tachtig steeds vaker bestudeerd aan de hand van aan de sociale wetenschappen ontleende vraagstellingen, maar dit betekende zeker niet het einde van de lokale casestudy waarin beschrijving van de gebeurtenissen de belangrijkste doelstelling was. In 1988 verscheen in Holland een artikel over de patriottentijd in Gorinchem, dat mogelijk het themanummer van het jaar ervoor niet had gered. De auteur, de Gorkumse gemeentearchivaris A.J. Busch, begon zijn bijdrage met de hierboven aangehaalde oproep van Th. Jorissen om 'Gorinchem in den patriottentijd ons te teekenen'. Busch liet dit citaat volgen door de woorden: 'Die uitdaging wordt hier aanvaard'. ${ }^{49}$ Dat de oproep van Jorissen inmiddels een eeuw oud was maakte voor deze auteur blijkbaar niet uit; dit toont de duurzaamheid van de geschiedopvatting dat voor iedere plaats eerst maar eens de historische feiten op een rij moeten worden gezet.

\section{Op de vertrouwde weg voort: 1990 tot nu}

In de literatuur die rondom 1987 verscheen beleefde een nieuwe generatie (kunst)historici haar doorbraak als revolutiespecialist. Niek van Sas, Wyger Velema, Joost Rosendaal en Frans Grijzenhout waren destijds allen betrokken bij één of

49 A.J. Busch, 'Greep naar de macht door patriotten in Gorinchem', Holland 20 (1988) 44-61, aldaar 44. 
meer herdenkingsbundels en zijn tot op de dag van vandaag werkzaam gebleven op het terrein van de Nederlandse revolutie; met hun publicaties hebben deze 'mannen van zevenentachtig' ${ }^{50}$ meer dan wie ook bijgedragen tot de huidige tendens om de periode tussen 1780 en 1801 (en soms tot 1813) te beschouwen als één tijdvak. Hoewel zij allen hun eigen accenten leggen, kunnen deze auteurs samen met enkele anderen worden gerekend tot een politiek-culturele stroming binnen de revolutiegeschiedschrijving, waarin de aandacht meer uitgaat naar ideeën en cultuuruitingen in enge zin (letterkunde, revolutionaire symboliek, enzovoort) maar ook naar de culturele dimensie van politieke praktijken. ${ }^{51}$

Dat de grens tussen deze politieke cultuurbenadering en de hiervoor besproken benaderingswijzen vloeibaar is, toont vooral het werk van Rosendaal, die zich van de genoemde auteurs ook het meest heeft gemanifesteerd op lokaalhistorisch vlak. Als Nijmeegse student in de jaren tachtig reeds een actief bijdrager aan allerlei lokaalhistorische tijdschriften en betrokken bij verschillende herdenkingsinitiatieven, studeerde Rosendaal in 1988 af op een doctoraalscriptie over de patriottenbeweging in de Langstraat en het Land van Heusden en Altena. Deze scriptie vormde de basis voor een bijna een kwarteeuw later in druk verschenen monografie over de stadjes en dorpen in dit Hollands-

50 Zoals in de Bataafse tijd met enige spot de in 1787 afgezette patriotse regenten werden genoemd; hier bedoeld als geuzennaam.

$5^{1}$ Zie voor een recente terugblik door de hoofdpersonen zelf: Frans Grijzenhout, Niek van Sas en Wyger Velema, 'Inleiding', in: Idem ed., Het Bataafse experiment. Politiek en cultuur rond 1800 (Nijmegen 2013) 725 , aldaar 14-15.
Brabantse grensgebied. ${ }^{52}$ Deze studie over de patriottentijd vormt misschien wel het beste voorbeeld van wat op gedegen onderzoek gebaseerde vergelijkende plaatselijke geschiedschrijving kan opleveren. Rosendaal beschrijft zeer precies de plaatselijke gebeurtenissen en heeft behalve voor de lokaal geformuleerde ideeën ook een meer sociaalhistorische belangstelling voor de gehanteerde collectieve actiemiddelen. Net als Nieuwenhuis eerder deed, kijkt Rosendaal niet alleen naar de verhoudingen binnen lokale gemeenschappen maar ook naar de verhoudingen tussen lokale gemeenschappen onderling en naar de verhouding tot de bovenlokale revolutionaire beweging. Ook hij komt daarbij tot de conclusie dat het vaak de plaatselijke verhoudingen waren die bepaalden wie in welk politiek kamp terechtkwam, en dat het conflict van de jaren 1780 behalve als een revolutionaire botsing van verschillende denkbeelden over goed bestuur op lokaal niveau toch vooral moet worden beschouwd als een voormoderne factiestrijd tussen lokale clans.

Het latere werk van Rosendaal is net als dat van de andere politieke cultuurhistorici veeleer gericht op de nationale (verbeelde) gemeenschap. ${ }^{53}$ Deze focus moet mede worden begrepen in het licht van een streven om de historische relevantie van het revolutietijdvak voor het heden sterker te benadrukken, een streven dat

$5^{2}$ Joost Rosendaal, Tot nut van Nederland. Polarisatie en revolutie in een grensgebied, 1783-1787 (Nijmegen 2012).

53 Een uitzondering vormt een wel lokaalhistorisch en deels politiek-cultureel georiënteerde bundel waarover Rosendaal de redactie voerde met Anton van de Sande: Dansen rond de vrijheidsboom. Revolutionaire cultuur in Brabant en de Franse invasie van 1793 (Den Bosch 1993), met bijdragen over Helmond en Eindhoven (C. Bergman), Gemert (T. Romme), en Zevenbergen (J. Rosendaal en O. Wismans). 
zijn oorsprong vond in het momentum van de herdenking van de patriottentijd. De veronderstelling lijkt te zijn geweest waarschijnlijk niet geheel ongegrond dat dit het meest overtuigend kon door onderzoek te doen naar de nationale dimensie van de Bataafse revolutie. Het gevolg was dat de lokale dimensie voortaan gemakkelijker werd overgelaten aan nietprofessionele historici. ${ }^{54}$ Een onbedoeld neveneffect van ' 1987 ' is daarmee geweest dat er in het lokaalhistorische revolutieonderzoek geen grote methodologische doorbraken meer hebben plaatsgevonden sinds de door de sociologie geïnspireerde vernieuwingsslag die in de jaren zeventig en vroege jaren tachtig onder invloed van het werk van Rudé en Tilly inzette. De meer op de culturele antropologie geënte cultural turn is aan lokale historici grotendeels voorbij gegaan. Een uitzondering vormt Eric Palmen, die een doctoraalscriptie schreef over de patriottentijd in Rotterdam en onderzocht hoe burgers zich in de publieke ruimte als orangist of

54 Vaak is opgemerkt dat halverwege de jaren negentig het tweede eeuwfeest van de Bataafse omwenteling tot veel minder herdenkingsliteratuur leidde dan eerder bij de patriottentijd het geval was geweest, maar dit beeld moet worden bijgesteld wanneer ook niet-professionele studies in overweging worden genomen. Zie onder meer J.M.J. van den Berg, 'Overschie en Hogenban in Bataafse en Franse tijden', in: I.A.F. Barjesteh van Waalwijk van Doorn en F.J. van Rooijen ed., Tussen Vrijheidsboom en Oranjewimpel. Bijdragen tot de geschiedenis van de periode 1795-1813 (Rotterdam 1995) 446-455; Richard Hermans, 'De Ware Vrijheid. Zutphen in 1795', Zutphen 15 (1995) 71-77; Gerrit Kraa, 'Wierden in de Franse Tijd', Jaarboek Twente 34 (1995) 115-124; Jan-Willem Scheider, 'Omwenteling in bedaarde tevredenheid. De remotie te Hilversum, januari 1795', Eigen Perk 15.4 (1995) 231-238; Han Verschure, Een dorp in de greep van de vrijheid. Waspik in de Franse tijd 1795-1813 (Waspik 1995); Liesbeth Boon, “"En nu die kale Fransen!" Woerden in de patriottentijd en de Bataafs-Franse tijd', Heemtydingen 32.3 (1996) 50-58. patriot presenteerden en van welk 'symbolisch vocabulaire' zij gebruikmaakten; zijn werk sluit daarmee aan bij dat van new cultural historians als Natalie Zemon Davis en Lynn Hunt. ${ }^{55}$

In 1999 verscheen de monografie Republikeinse veelheid, democratisch enkelvoud. Sociale verandering in het Revolutietijdvak. 's-Hertogenbosch 1770-1820 van Maarten Prak. ${ }^{56}$ Tien jaar eerder was Prak zijn onderzoek begonnen in het kader van het Utrechts-Groningse project 'Integrale Geschiedenis', dat tot doel had 'de verbrokkeling tegen te gaan die de geschiedwetenschap door een groeiend aantal specialismen en invalshoeken [was] gaan vertonen' en daarbij zocht naar 'wegen om die uiteenlopende benaderingen van het verleden opnieuw te integreren'. ${ }^{57}$ Dit kreeg concreet zijn uitwerking in een onderzoek naar de (regio's rondom) Groningen en Den Bosch tussen 1770 en 1914. De publicaties die het trouwst bleven aan de 'integrale' langetermijnbenadering leverden voor het revolutietijdvak weinig opzienbarends op: zo bevatte de door Pim Kooij geredigeerde bundel Dorp naast een stad, over het Groningse dorp Hoogstad, een apart hoofdstuk over de periode tussen 1770 en 1815 , dat vooral de politiekbestuurlijke veranderingen behandelde

55 Eric Palmen, 'Wie zou ook niet vrolyk weezen. Een historisch-antropologische studie naar de partijstrijd tussen de patriotten en orangisten in Rotterdam, 17831784' (doctoraalscriptie Rotterdam 1992). Zie ook Idem, 'Oranjebitter. De smalle gemeente van Rotterdam in de partijstrijd tussen de patriotten en orangisten', Rotterdamsch Jaarboekje, $10^{\mathrm{e}}$ reeks, 2 (1994) 243261. 56 Maarten Prak, Republikeinse veelheid, democratisch enkelvoud. Sociale verandering in het Revolutietijdvak 1770-1820 (Nijmegen 1999).

57 Pim Kooij ed., Dorp naast een stad. Hoogkerk 17701914 (Assen 1993) 3. 


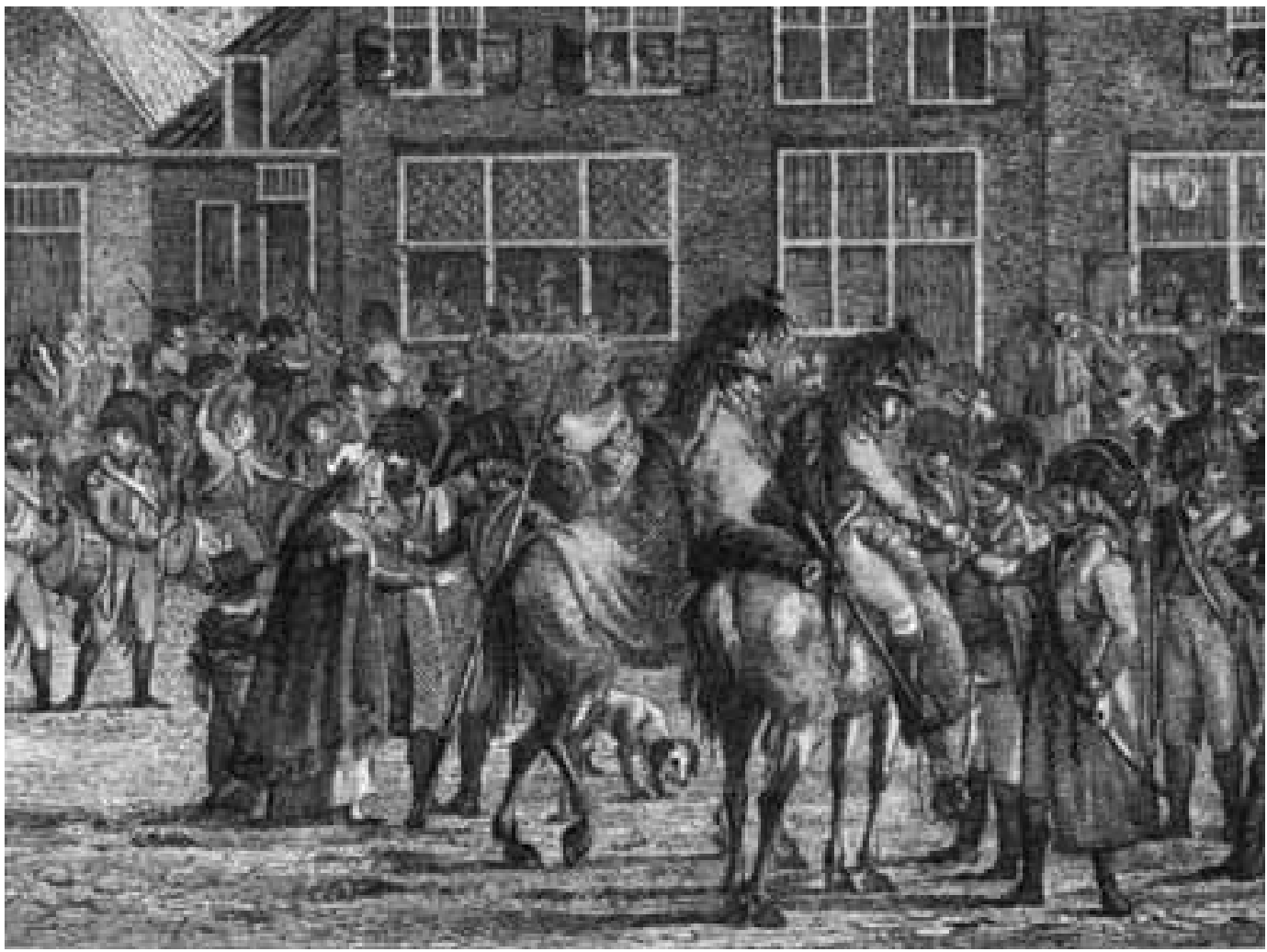

De Fransen trekken door de Haagpoort Breda binnen, 1793 (detail). Prent door Joannes Bemme naar een tekening van Dirk Langendijk, 1800-1802.

Rijksmuseum Amsterdam

en zich in weinig onderscheidde van het aloude beschrijvende genre. ${ }^{58}$

In zijn onderzoek naar Den Bosch stapte Prak uiteindelijk af van zowel de integralistische pretentie als van de longue durée en schreef hij een boek over het tijdvak dat ancien regime en restauratie met elkaar verbond. Methodologisch is zijn werk verwant aan dat van Tilly en Te Brake maar ook schatplichtig aan een Duitse stroming binnen de sociale geschiedschrijving die de lokale context niet centraal stelt 'om pragmatische redenen' van hanteerbaarheid maar uit principiële overwegingen en grote betekenis

58 Maarten Duijvendak, 'Maatschappelijke verhoudingen 1770-1815', in: Kooij ed., Dorp naast een stad, 205-224. toekent aan de stedelijke autonomie in de premoderne tijd. ${ }^{59}$ Prak koos voor de stedelijke casus om aan de hand daarvan te laten zien hoe in Nederland aan die autonomie een einde kwam rond 1800. Waar de opstand van de patriotten in zijn casus een corporatistisch karakter had en bescherming van lokale privileges de voornaamste inzet vormde, vielen lokaal burgerschap, lokaal georganiseerde sociale zorg en de corporatieve organisatie in gilden en schutterijen in de Bataafs-

59 Prak, Republikeinse veelheid, 18-19. Zie ook Maarten Prak, "Kommunalismus" en de steden in de Noordelijke Nederlanden ten tijde van de Republiek', Noordbrabants Historisch Jaarboek 17-18 (2000-2001) 10-44. 
Franse tijd ten prooi aan een immer toenemende centralisatie.

Als een van de weinige lokale revolutiehistorici heeft Prak ook school gemaakt. Zijn promovendus Thomas Poell verdedigde in 2007 een proefschrift waarin hij net als Prak trachtte het staatsvormingsproces in het revolutietijdvak beter te begrijpen door het te bekijken op stedelijk niveau. ${ }^{60}$ Op basis van zijn onderzoek naar Amsterdam bevestigde hij Praks conclusie dat de patriotse fase van de revolutie uiteindelijk neigde naar een versterking van de lokale autonomie. Meer dan Prak zag Poell ook al in de patriottentijd pogingen om lokale privileges en corporatistische structuren af te breken, maar deze faalden volgens hem omdat de democratische pretentie van de patriotse hervormers het noodzakelijk maakte om ook de meerderheid die zich hiertegen bleef verzetten een stem te geven. Verregaande centralisatie bleek volgens Poell pas mogelijk nadat eerdere democratisering was teruggedraaid, en zelfs toen bleef het verzet in Amsterdam tegen onder meer het creëren van een nationale gewapende burgermacht en het afschaffen van de gildes veel groter dan Prak eerder voor Den Bosch had geconstateerd.

In 2014 promoveerde E.H. de Jong als buitenpromovendus van Maarten Prak op een proefschrift over de strijd tussen Leidse patriotten en orangisten tussen 1775 en $1795 .{ }^{61}$ Het betreft een voorbeeldig uitgevoerde Tillyaanse studie naar vormen van collectieve actie, die laat zien dat de bestudeerde groeperingen terug-

6o Thomas Poell, The democratic paradox. Dutch revolutionary struggles over democratisation and centralisation (1780-1813) (dissertatie Utrecht 2007).

61 E.H. de Jong, Weldenkende burgers en Oranjeliefhebbers. Patriotten en prinsgezinden in Leiden 1775-1795 (Hilversum 2014, dissertatie Utrecht). grepen op een vertrouwd repertoire van actievormen maar dat daarbinnen ook ruimte was voor vernieuwing. De Jongs boek heeft een lange totstandkomingsgeschiedenis en getuigt van een diepgaande kennis van de bronnen. Ditzelfde geldt voor de kloeke dissertaties van twee andere buitenpromovendi, die beiden in de jaren tachtig al afstudeerden op de revolutie op lokaal niveau. Het eerste, van W.A. Knoops over Gouda in de patriottentijd, is een klassiek 'geschiedverhaal' waarin de gebeurtenissen centraal staan. ${ }^{62}$

Het tweede is strikt genomen geen lokaalhistorische maar een regionaalhistorische studie, maar verdient hier toch genoemd te worden. Een revolutie ontrafeld. Politiek in Friesland 1795-1798 van Jacques Kuiper is allereerst uitstekend geschreven en vormt een zeldzaam voorbeeld van hoe een verhalende benadering tegelijkertijd zeer analytisch kan zijn. ${ }^{63}$ De politieke strijd in Friesland was gedurende de Bataafse revolutie niet alleen heftiger maar waarschijnlijk ook complexer dan elders in Nederland, maar zij was onder meer een strijd tussen enerzijds ultra's in de hoofdstad Leeuwarden en enkele andere radicale bolwerken en anderzijds de gematigder en soms zelfs unverfroren orangistische inwoners van de plattelandsgemeenten in het zuiden en oosten van het gewest. Enigszins in lijn met wat eerder Schutte al vaststelde voor de Hollandse banne Graft concludeert Kuiper dat in de dorpen van de Friese Wouden de verticale gemeenschapszin, 'dorpisme' zoals hij het noemt, dusdanig was dat de bevolking er

62 W.A. Knoops, Gouda 1787. Radicalisering, revolutie, restauratie (Amsterdam 2011, dissertatie VU) 13. 63 Jacques Kuiper, Een revolutie ontrafeld. Politiek in Friesland 1795-1798 (Franeker 2002, dissertatie Groningen). 


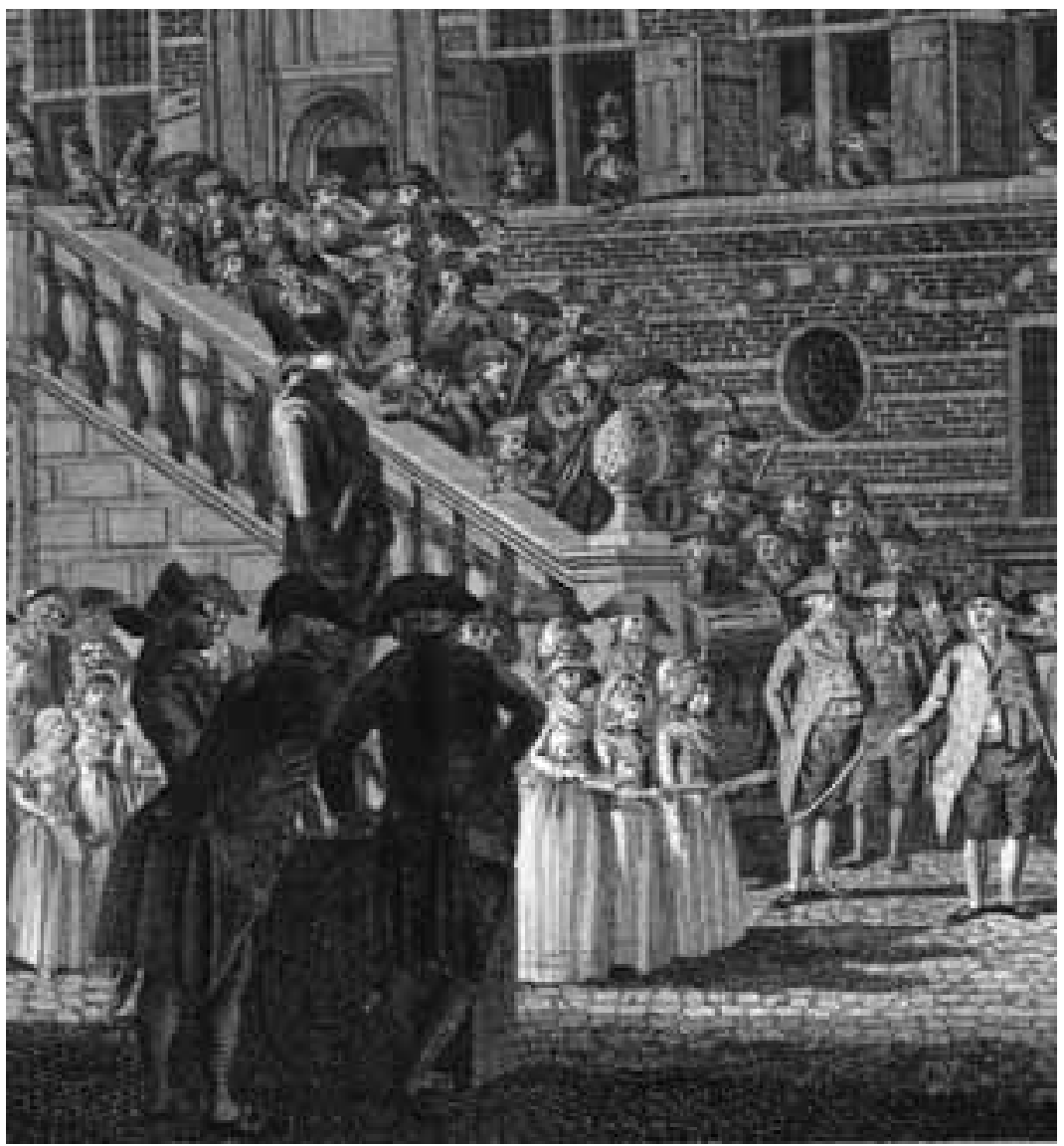

Vrijheidsboom opgericht voor het stadhuis te Alkmaar, 1795 (detail). Prent door Willem Kok naar een tekening van Johannes Petrus van Horstok, 1795 .

Rijksmuseum Amsterdam

weinig vatbaar was voor egalitair revolutiedenken. Dit lag anders in het meer verstedelijkte noorden en westen 'waar men vanouds individualistischer was ingesteld'. ${ }^{64}$ Ook religieuze overtuiging speelde in Friesland een belangrijke rol: waar de aanwezigheid van katholieken sterker was, kreeg radicalisme meer voet aan de grond.

Kuiper besteedt in zijn boek veel aandacht aan de werking van de democratie op stedelijk niveau in de eerste jaren van de Bataafse Republiek. Hij erkent daarbij zijn schatplichtigheid aan de 'trendsetter'

64 Ibidem, 516. op dit gebied, wiens werk tot nu toe ongenoemd is gebleven. ${ }^{65}$ Van de hand van R.E. de Bruin verscheen reeds in 1979 in dit tijdschrift het artikel 'Democratie in Utrecht 1795-1798', dat de opmaat vormde voor zijn proefschrift uit 1986 over de stad Utrecht tussen 1795 en $1813 .{ }^{66}$ Net als in

65 Ibidem, 18.

66 R.E. de Bruin, 'Democratie in Utrecht 1795-1798', TvG 92 (1979) 377-39o; R.E. de Bruin, Burgers op het kussen. Volkssoevereiniteit en bestuurssamenstelling in de stad Utrecht, 1795-1813 (Zutphen 1986, dissertatie Utrecht). Van De Bruin verscheen ook een beknopte studie over Utrecht in de patriottentijd: Revolutie in Utrecht. Studenten, burgers en regenten in de Patriottentijd 1780-1787 (Utrecht 1987). 
zijn latere werk regelmatig het geval zou zijn, stonden twee met elkaar samenhangende aspecten hier centraal: de uitwerking in de politieke praktijk van het revolutionaire beginsel van de volkssoevereiniteit in regeringsreglementen en verkiezingsstelsels, en de gevolgen hiervan voor de samenstelling van het bestuur. Zijn aandacht voor vormen van directe democratie in grond- en wijkvergaderingen kreeg behalve bij Kuiper ook bij anderen navolging, al blijft er over het grassrootsniveau nog veel onduidelijk. ${ }^{67}$

Inmiddels kan De Bruin, sinds 1993 conservator geschiedenis bij het Centraal Museum en sinds 2001 ook bijzonder hoogleraar Utrecht Studies, worden betiteld als de grand old man van de lokale en regionale revolutiegeschiedschrijving. Deze status heeft hij onder andere te danken aan het feit dat hij in langetermijngeschiedenissen over stad en gewest Utrecht als vanzelfsprekend de revolutiejaren voor zijn rekening nam. ${ }^{68}$ De Bruin is een van de dragende vakhistorici geweest in de tendens, ingezet in de jaren negentig, om zo'n beetje iedere stad van enige beteke-

67 Barbara Resink en Jort Verhoeven, 'De stem van het volk. De Amsterdamse wijkvergaderingen in de eerste jaren der Bataafse revolutie', Amstelodamum 82.2 (1995) 33-43; R. van der Woude, 'Gelijkheid op krukken. De Bataafse revolutie in de stad Groningen, 1795-1803', Gronings Historisch Jaarboek (1995) 39-63 (gebaseerd op doctoraalscriptie Groningen 1989); Annie Jourdan, 'Amsterdam klem tussen staat en volk. Een bedreigde municipaliteit (1795-1798)' in: I. Nijenhuis, J. Roelevink en R. Sluijter ed., De leeuw met de zeven pijlen: Het gewest in het landelijk bestuur (Den Haag 2010) 95-108; Pepijn Brandon en Karwan FatahBlack, 'De oppermagt des volks'. Radicale democraten in Leiden tussen nationaal ideaal en lokale werkelijkheid (1795-1797)', Holland 43 (2011) 3-23.

68 Voor de stad Utrecht is dit: R.E. de Bruin, 'Regenten en revolutionairen (1747-1851)', in: Idem e.a. ed., 'Een paradijs vol weelde'. Geschiedenis van de stad Utrecht (Utrecht 2000) 315-373. nis te voorzien van een (nieuwe) stadsgeschiedenis. ${ }^{69}$ Een positief effect van deze prestigeprojecten was dat het revolutietijdvak er een volwaardig onderdeel werd van de stedelijke langetermijngeschiedenis. De hoofdstukken over de laatste decennia van de achttiende eeuw werden meer dan eens geschreven door specialisten als Rosendaal, Prak en Poell. ${ }^{70}$

In 2000 deed De Bruin met een artikel over 'Lokale bestuurders in Holland en Utrecht, 1795-1798' een zeldzame poging om mede op basis van lokaalhistorische literatuur uitspraken te doen die de lokale en zelfs de gewestelijke context overstijgen. ${ }^{71}$ Hij greep daarvoor terug op zijn eigen proefschrift en het werk van auteurs als Nieuwenhuis en Schutte, maar ge-

69 Zie Pim Kooij, 'Het format van de stad. Een evaluatie van recente Nederlandse stadsgeschiedenissen', $B M G N$ 117.3 (2002) 293-306; Paul van de Laar en Arie van der Schoor, 'Nieuwe stadsstudies besproken', Tijdschrift voor Sociale en Economische Geschiedenis 3.3 (2006) 143-147; R.E. de Bruin, 'Nieuwe stadsgeschiedenissen in beeld', $B M G N$ 122.3 (2007) 411-424; Jan Hein Furnée, 'Naar een integrale geschiedenis van de negentiende-eeuwse stad. Vijftien stadsbiografieën in perspectief, De Negentiende Eeuw 33.2 (2009) 96-122. 70 Maarten Duyvendak en Maarten Prak, 'Revolutie op revolutie. Politiek en bestuur', in: Aart Vos e.a. ed., 's-Hertogenbosch. De geschiedenis van een Brabantse stad 1629-199o (Zwolle [etc.] 1997) 217-239; Joost Rosendaal, 'Verlichting, revolutie en behoud. Economie, cultuur en politiek 1780-1814', in: Cock Gorisse e.a. ed., Tilburg, stad met een levend verleden. De geschiedenis van Tilburg vanaf de steentijd tot en met de twintigste eeuw (Tilburg 2001) 193-218; Thomas Poell, 'Het einde van een tijdperk. De Bataafs-Franse tijd 1795-1813', in: Willem Frijhoff en Maarten Prak ed., Geschiedenis van Amsterdam II.2 (Amsterdam 2005) 428-499.

71 R.E. de Bruin, 'Door het soevereine volk gekozen. Lokale bestuurders in Holland en Utrecht, 1795-1798', Holland 32.1/2 (1999) 22-36. Enkele jaren eerder had De Bruin al eens iets vergelijkbaars ondernomen: 'Gefragmenteerde volkssoevereiniteit. Democratie op lokaal en regionaal niveau', in: O. Moorman van Kappen en E.C. Coppens ed., De Bataafse omwenteling en het recht (Nijmegen 1997) 79-96. 
bruikte bijvoorbeeld ook binnen lokaalhistorische verenigingen tot stand gekomen studies over dorpen als Veenendaal, Houten en Westbroek. ${ }^{72}$ Op basis van al deze literatuur trok hij vergelijkende conclusies over onder meer de sociale en politieke samenstelling en mate van radicaliteit van lokale besturen en over de betekenis van de religieuze verhoudingen, de verhouding tot andere dorpen of steden in de omgeving en de opstelling van de Fransen voor het plaatselijke verloop van de revolutie.

Met zijn profiel werd De Bruin als vanzelfsprekend een sleutelfiguur binnen een opmerkelijk provinciaal project dat na een lange voorgeschiedenis in 2007 van start zou gaan. Erfgoedspecialisten, archivarissen, lokaalhistorische verenigingen en Piet 't Hart, De Bruins voorganger op de leerstoel Utrecht Studies, vonden elkaar in een belangstelling voor bestuurlijke elites. Toen het Utrechtse provinciebestuur rond 2000 liet uitzoeken of er meer lijn viel te brengen in het subsidiebeleid voor historisch onderzoek, resulteerde dit in een 'Leemtelijst geschiedschrijving provincie Utrecht' waarop het thema bestuurlijke elite bovenaan prijkte. ${ }^{73}$ Er werd een onderzoeksgroep 'elite' opgericht die onderzoek ging doen naar het gewestelijke

72 Kees van Schaik, 'De Bataafse omwenteling in Houten en 't Goy', Tussen Rijn en Lek 29.4 (1995) 84104; Roelof Bisschop, Een tweeling zelfstandig. Stichts en Gelders Veenendaal in de Bataafse-Franse Tijd, 17951813 (Veenendaal 1995); M. L. de Raadt-Nolst Trenité, 'Westbroek tijdens de Bataafse Republiek 1795-1806', St Maerten 14 (1995) 8-16.

73 Mieke Heurneman, Waard om te weten. Leemtelijst geschiedschrijving provincie Utrecht (Utrecht 2007). bestuur en de lokale besturen van een beperkt aantal Utrechtse plaatsen rondom de ijkjaren $1747,1786 / 1787,1795,1813 / 1815$ en $1848 / 1851{ }^{74}$ De onderzoekers, onder wie beroepshistorici en niet-professionele historici, publiceerden de resultaten van hun onderzoek in lokaalhistorische tijdschriften. ${ }^{75}$ Het sluitstuk van het project vormde een themanummer van het Jaarboek Oud-Utrecht in 2011. ${ }^{76}$

Waar de verschillende deelstudies over het revolutietijdvak vooral een toevoeging in de breedte bieden omdat ze de vragen centraal stellen die in het lokaalhistorische onderzoek al een eeuw lang meestal centraal hadden gestaan ('Wie zaten er op het pluche $[\ldots]$ en wat deden ze daar precies? ${ }^{77}$ ), ligt de meerwaarde van dit project vooral in de ambitie om zowel synchroon en diachroon te vergelijken en daarbij ook te kijken naar ijkjaren die veel minder vaak

74 Jos Wassink, 'De aftrap van "Waard om te weten". Onderzoek naar de bestuurlijke elite in de provincie Utrecht', in: Wisseling van de wacht. Stichtse bestuurders in een roerige eeuw, [themanummer] Jaarboek Oud-Utrecht (2011) 6-11.

75 Zie bijvoorbeeld voor het revolutietijdvak: Edwin Maes, "Van kluisters wars en slavernij, de zinspreuk hier is: dood of vrij". De patriotse revolutie te Wijk bij Duurstede (1783-1787)', Jaarboek Oud-Utrecht (2007) 69-113; Mieke Heurneman, 'Patriotten, Prinsgezinden en Pruisen. Onderzoek naar de elite van Soest rond 1787', Van Zoys tot Soest 29.1 (2008) 1-14 en 29.2 (2008) 1-11; Willem H. Strous, 'Gestaalde bestuurders in Rhenen tussen 1795-1815', Oud Rhenen 29.1 (2010) 13-33; K. Strengers-Olde Kalter, 'Kansen voor revolutionair en katholiek. Bestuurlijke omwenteling in Maarssen 1795-1798', Periodiek van de Historische Kring Maarssen 38.1 (2011) 15-23.

76 Zie hierin voor het revolutietijdvak: Nettie Stoppelenburg, 'De patriotten van Oudewater. Idealisme en harde realiteit' (66-87); Edwin Maes, "Vrijheid, Gelijkheid, Broederschap of de Dood!" Wijkse "revolutionaire" omwentelingen gedurende de periode 17951798' (144-158); Mieke Heurneman, "'t Vrije volk van Zoest”. De Bataafse Revolutie in Soest, 1795-1798' (159174).

77 Wisseling van de wacht, achterflap. 
bestudeerd zijn dan de revolutiejaren. In het slotartikel van het themanummer kon De Bruin op basis van het verrichte onderzoek vaststellen dat het bestaande maar nooit systematisch getoetste beeld van de wijze waarop de bestuurssamenstelling zich tussen 1747 en 1851 ontwikkelde grotendeels juist was: in Utrechtse besturen waren tot het revolutietijdvak steeds dezelfde families vertegenwoordigd, soms aangevuld door vertrouwelingen van de stadhouder. Vanaf de patriottentijd doken in de besturen nieuwe namen op en dit proces bereikte een hoogtepunt in 1798 , maar vanaf 1801 begonnen bestuurders die eerder van het toneel waren verdwenen hun plaats weer in te nemen naast homines novi met een lange adem. In het Koninkrijk werden bestuursfuncties weer in toenemende mate vervuld door telgen van de oude regentenfamilies, tot er na 1848 geleidelijk weer ruimte kwam voor verjonging en vernieuwing. ${ }^{78}$

\section{Besluit}

De patriottentijd en de Bataafse tijd vormen al ruimschoots een eeuw een bron van fascinatie voor niet-professionele historici die geïnteresseerd zijn in de geschiedenis van hun eigen dorp of stad. Het idee dat hun nu zo rustige gemeente ooit het toneel vormde voor revolutionaire taal en heftige politieke strijd spreekt tot de verbeelding. Deze historici huldigen meer dan eens de zienswijze dat de revolutietijd voor een bepaalde plaats 'al wel' of 'nog niet' beschreven kan zijn: wanneer een beschrijving in druk is verschenen is dat dorp in

78 Renger de Bruin, 'Utrechtse bestuurders tussen ware vrijheid en democratie', in: Wisseling van de wacht, 286-304, aldaar 303. principe 'klaar'. Zo bezien is de lokale revolutiegeschiedschrijving in theorie eindig: er komt een moment dat van iedere plaats waarvoor de bronnen het enigszins toelaten de geschiedenis is opgetekend.

Zo ver is het nog niet, maar er is inmiddels wel behoorlijk wat vorswerk verricht. Daarnaast bestaan er de nodige studies van vakhistorici. De vraag werpt zich op hoe de geschiedwetenschap kan voortbouwen op al dit onderzoek. Ik doe hier tot besluit van deze bijdrage enkele suggesties in een richting die misschien voor de hand lijkt te liggen, maar opvallend genoeg nog nauwelijks is beproefd: die van de vergelijkende literatuurstudie. Een duidelijke meerwaarde hebben nu al de monografieën van auteurs als Nieuwenhuis, Rosendaal en Kuiper die op basis van bronnenstudie lokale casussen met elkaar vergelijken, maar er zijn uiteraard grenzen aan het bronnenonderzoek dat door één historicus kan worden verricht. De weg van de vergelijking op basis van literatuur is gewezen door De Bruin, die een veelbelovende eerste indruk heeft gegeven van de mogelijkheden die het vergelijkende genre biedt.

Vergelijkingen zijn tot nog toe beperkt gebleven tot lokale casussen binnen een bepaalde regio, terwijl het aan de hand van het beschikbare deelonderzoek nu heel goed mogelijk zou zijn het lokale niveau op nationale schaal met elkaar te vergelijken en algemene conclusies te trekken over het revolutietijdvak. We kunnen hier het voorbeeld nemen van het proces van burgerwapening dat zich gedurende de patriottentijd in de Republiek voltrok. Stephan Klein heeft vanuit een politiek-culturele invalshoek veel bijgedragen tot begrip van de intellectuele achtergronden van dit verschijnsel, maar richt zich vooral op de 
stedelijke exercitiegenootschappen zoals die vanaf 1783 werden opgericht in bijvoorbeeld Utrecht en Deventer. ${ }^{79}$ In zijn boek over het Land van Heusden en Altena en de Langstraat gaat Joost Rosendaal ook in op het platteland. Vanwege een dreigende inval van de Habsburgse keizer Josef II in de Republiek riepen de Staten van Holland en West-Friesland (waarin patriotten de overhand hadden) in november 1784 op tot wapening van het platteland. Waar historici als Colenbrander en Geyl eerder hadden geconcludeerd dat de plattelandsbevolking zich hiertegen massaal had verzet, schetst Rosendaal een veel gedifferentieerder beeld van Zuid-Hollandse dorpen waar meer of minder verzet bestond en dorpen waar juist met veel enthousiasme werd gereageerd. ${ }^{80}$

Ter vergelijking verwijst Rosendaal naar het werk van Nieuwenhuis, die had vastgesteld dat in de Noord-Hollandse dorpen Durgerdam, Ransdorp en Holisloot 'vrijwel niemand [...] zich [liet] excuseren'. ${ }^{81}$ Aan de hand van de beschikbare lokale casestudy's zou dit beeld verder kunnen worden uitgebreid en verfijnd en zou het mogelijk zijn om patronen waar te nemen. Waar in de Republiek kwam burgerwapening spontaan tot stand en waar was er sprake van druk van bovenaf? Waardoor werd de houding van de plaatselijke bevolking ten aanzien van de burgerwapening bepaald? Hoe verliep het proces bijvoorbeeld in Groningen, Vreeswijk, IJsselstein, Leiderdorp, De

79 S.R.E. Klein, Patriots republikanisme. Politieke cultuur in Nederland (1766-1787) (Amsterdam 1995) hoofdstuk 5 .

80 Rosendaal, Tot nut van Nederland, 41-48.

81 Nieuwenhuis, Keeshonden en Prinsmannen, 78.
Zijpe, Goes, Almelo, of Beilen? ${ }^{82}$ Volgens Klein hing de 'vorm waarin de burgerwapening gestalte kreeg $[. .$.$] af van de politieke$ verhoudingen ter plaatse'. ${ }^{83}$ Andere factoren die afgaande op lokale deelstudies een rol kunnen hebben gespeeld zijn de sociale en religieuze samenstelling van de bevolking, de mate van sociale cohesie, de bestuurlijke tradities en oude rivaliteiten, en de verhouding tot naburige gemeenten en het gewestelijke bestuur. Vergelijking zou het mogelijk maken een kwalitatieve afweging te maken van het relatieve belang van dergelijke factoren.

Een brede, vergelijkende studie naar één aspect zou op deze manier ook een venster kunnen bieden op de landelijke verspreiding van patriots enthousiasme (of juist het gebrek daaraan) op lokaal niveau en de rol die supralokale actoren daarbij speelden; in Rosendaals casus bleek de 'opkomst en mate van bereidwilligheid $[. .$.$] een afspiegeling van het poli-$ tieke landschap en de polarisatie die deze streek de volgende jaren zou verdelen' ${ }^{84}$

82 J.K.H. van der Meer, Patriotten in Groningen, 17801795 (Assen 1996, dissertatie Groningen) 45-50; M. Verhoef, 'Vreeswijk in de patriottentijd 1780-1787', Cronyk de Geyn 19.2 (1997) 22-39, aldaar 24; Fred Vogelzang, 'Een aarzelende machtsstrijd. IJsselstein tijdens de eerste patriotse opstand 1785-1788', Jaarboek OudUtrecht (2004) 63-118; Edward Sodderland, 'De vlam van oproer. De patriotse revolutie in Leiderdorp 1784-1787', Jaarboekje voor Geschiedenis en Oudheidkunde van Leiden en Omstreken 104 (2012) 152-175, aldaar 154; Annet Jonker, 'Beroering in de polder. De Zijpe tijdens de patriottentijd, de Bataafse Periode en de Engels-Russische invasie', Zijper historie bladen 19.3 (2001) 3-24, aldaar 9; F. van Dijk, 'Goes in de patriottentijd', Spiegel Der Historie 4 (1969) 49-136, aldaar 86; J.K. Abbes, De Almelose patriottenbeweging (de strijd om de democratische burgemeestersverkiezing (1783-1786) (Enschede 1997) 24; G. Dijkstra, 'Patriotten in Beilen. Thomas Muntingh kiest het hazepad', Ons waardeel 7.2 (1987) 41-56, aldaar 42.

83 Klein, Patriots republikanisme, 184.

84 Rosendaal, Tot nut van Nederland, 42. 


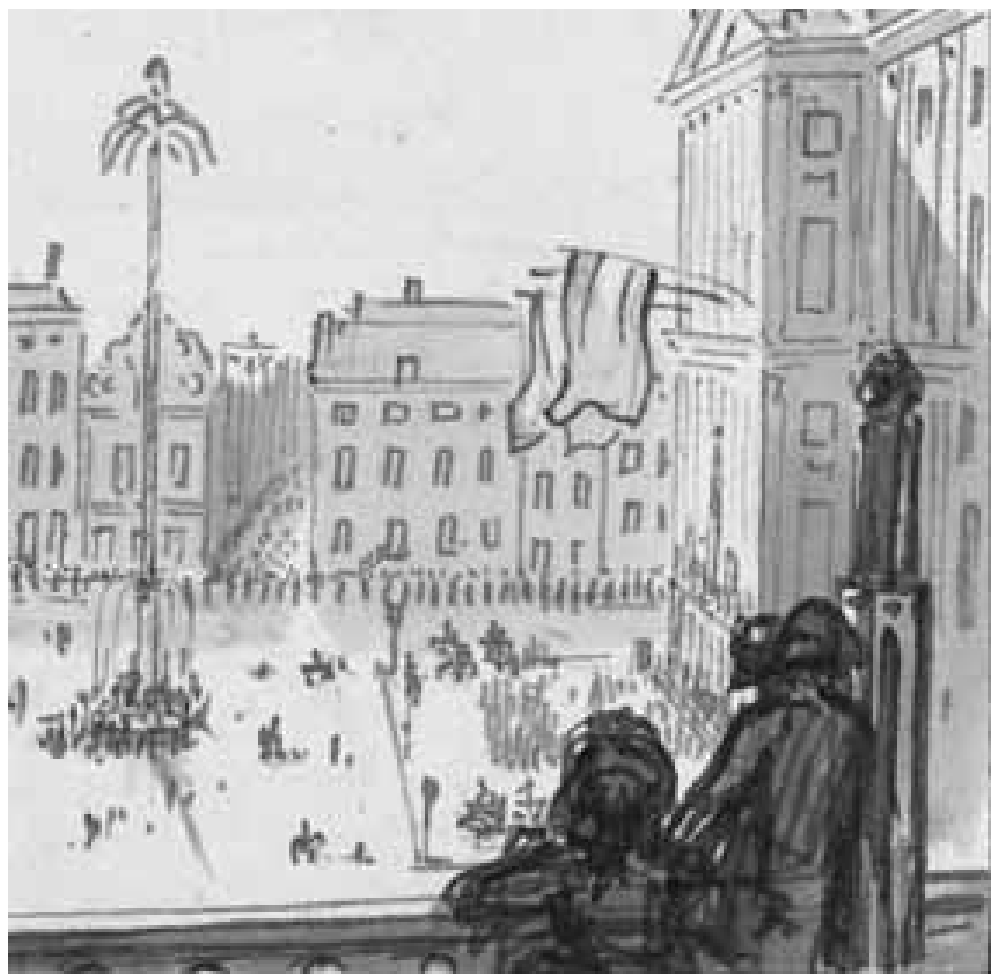

Het feest van de vestiging der constitutie op de Dam te Amsterdam, 19 mei 1798 (detail). Tekening door Jurriaan Andriessen, 1798.

Rijksmuseum Amsterdam

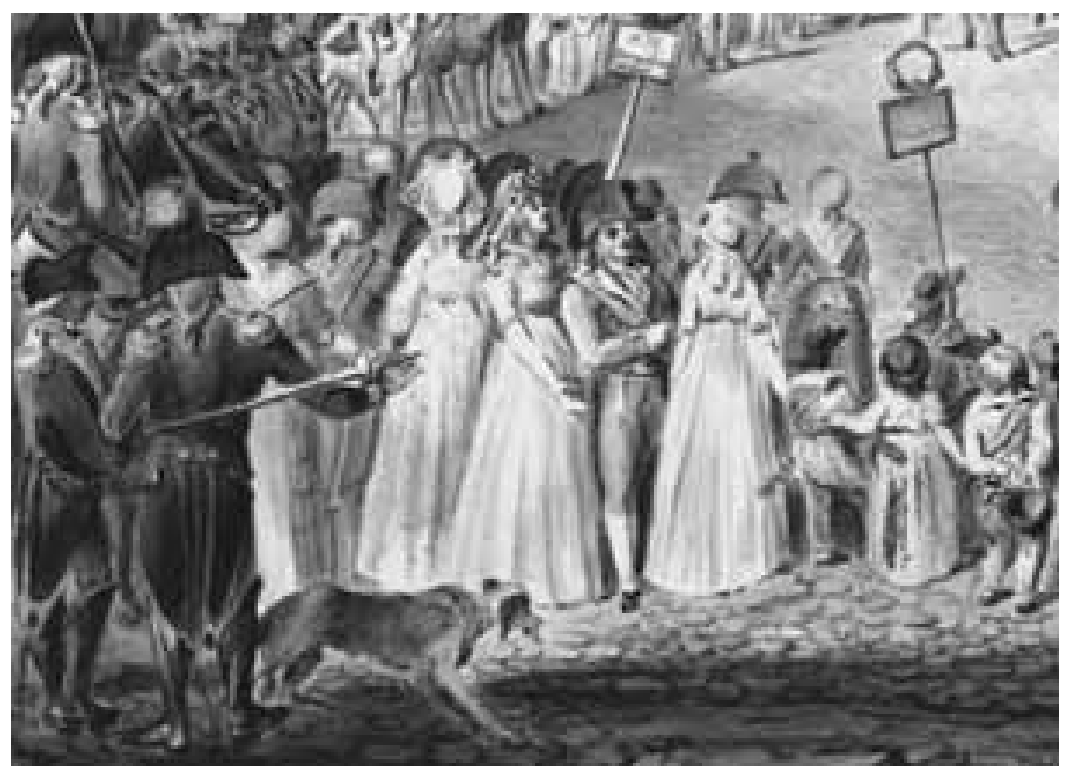

Viering van het constitutiefeest in Leeuwarden, 19 mei 1798 (detail). Tekening door Petrus Groenia, 1798. Historisch Centrum Leeuwarden 
De mate van patriots enthousiasme zou vervolgens kunnen worden afgezet tegen de geestdrift waarmee lokale burgers in 1795 de omwenteling bewerkstelligden; behalve in enkele hier besproken langetermijnstudies is de vraag hoe de lokale actiebereidheid in de patriotse en de Bataafse tijd zich tot elkaar verhouden nog zelden gesteld. ${ }^{85}$ Een vergelijkende studie naar de eerste maanden van 1795 ligt sowieso voor de hand en opnieuw zou dit heel goed kunnen op basis van literatuuronderzoek, terwijl ook de ooggetuigenverslagen waarnaar in veel studies wordt verwezen hier zeker van nut kunnen zijn. ${ }^{86}$ De niet-professionele lokale deelstudies over de Bataafse fase in de revolutie besteden vaak aandacht aan een aantal vaste sleutelmomenten in het revolutionaire proces. Eén zo'n ijkmoment is ook de fase die aanbrak na de staatsgreep van 22 januari 1798 en de wording van de eenheidsstaat inleidde. Een vergelijkende analyse van de effecten van deze staatsgreep op lokaal niveau is danig gewenst.

85 Een uitzondering vormt J.C. Streng, 'Aan weerszijden van de Franse revolutie', Overijsselse historische bijdragen 111 (1996) 105-116 (over Zwolle).

86 Zie voor (verwijzingen naar) ooggetuigenverslagen bijvoorbeeld J.C. van Slee, 'De omwenteling te Deventer in 1795', Verslagen en Mededeelingen van de Vereeniging tot beoefening van Overijsselsch Regt en Geschiedenis 38 (1921) 68-74; H.L. Driessen, 'Wageningen en de revolutie van 1795', Bijdragen en Mededelingen van de Vereniging Gelre 38 (1935) 299-310; A.G. Pikkemaat, Bataafse vrijheid in Nijmegen 1794-1795 (Nijmegen 1963, dissertatie Nijmegen); H.L.Ph. Leeuwenberg, 'De Bataafse Omwenteling te Zeist. Aantekeningen uit het Gemeindiarium van de Evangelische Broedergemeente te Zeist, 4 januari- 5 februari 1795', in: C. Dekker e.a. ed., Nederlandse Historische Bronnen III (Amsterdam 1983) 147-194; Renger de Bruin, 'Revolutieverslag op receptenpapiertjes. Het dagverhaal van Hendrik Keetell, 1793-1816', in: Marco van Egmond e.a. ed., Bijzonder onderzoek. Een ontdekkingsreis door de Bijzondere Collecties van de Universiteitsbibliotheek Utrecht (Utrecht 2009) 72-77.
Ook zou het interessant zijn om vergelijkenderwijs na te gaan wanneer de revolutie op lokaal niveau 'eindigde', bijvoorbeeld door te kijken naar de terugkeer van oude bestuurders of naar het symbolische moment dat de plaatselijke vrijheidsboom door burgers of autoriteiten werd neergehaald. ${ }^{87}$

De niet-professionele lokale revolutiegeschiedschrijving kan door haar specifieke, overwegend beschrijvende aard waardevol zijn als een vorm van vooronderzoek, eigenlijk niet eens zo heel anders dan hoe Jorissen en De Blécourt het zich ooit voorstelden, maar bijvoorbeeld ook zoals een sociaalwetenschappelijk georiënteerd historicus als Charles Tilly in zijn recentere werk voor ogen had. ${ }^{88}$ Dat

87 Zie hiervoor onder meer het Utrechtse project 'Waard om te weten' en bijvoorbeeld L. Buning, Het herenbolwerk. Politieke en sociale terreinverkenningen in Drenthe over de periode 1748-1888 (Assen 1966); J. Otsen, 'Patriotten, Bataven en Franzosen in Purmerend. Bestuurlijke ontwikkelingen van 1783 tot 1816 ', Nederlandse Historiën 23 (1989) 60-80; S.W. Verstegen, Gegoede ingezetenen. Jonkers en geërfden op de Veluwe tijdens Ancien Régime, Revolutie en Restauratie (16501830) (Zutphen 1990); Annemarie den Hertog, 'Revolutie en restauratie. Het dorpsbestuur van Hilversum tijdens de Bataafse Republiek 1795-1806', Eigen Perk 16.4 (1996) 163-181; Kees Vossestein, Verwisselde loterijbriefjes. Montfoort 1783-1803 (Hilversum 1999); J.K. de Klerk, 'De stad Arnhem in de Bataafse Tijd (17951806)', Arnhem de genoeglijkste 23.2 (2003) 54-68.

88 Zie bijvoorbeeld Charles Tilly en Sidney Tarrow, Contentious politics (Boulder 2007) passim. Tilly en Tarrow stellen voor een vergelijkende bestudering van contentious politics voor om eerst een event catalogue op te stellen: het identificeren van golven van parallelle gebeurtenissen waarin aan de hand van vergelijkbare actievormen vergelijkbare doelen worden nagestreefd. Zo'n catalogus kan worden opgesteld aan de hand van 'any source that regularly records contentious politics in a relatively uniform way'. De vele lokaalhistorische casestudy's waarover we inmiddels kunnen beschikken lijken hiervoor uitermate geschikt. Doel van deze exercitie is te bepalen via welke mechanismen en processen episodes van politieke spanning verlopen. 
dit potentieel tot nu toe maar in geringe mate is benut heeft er in de eerste plaats mee te maken dat de grens tussen professionele geschiedschrijving en wat 'amateurgeschiedschrijving' is gaan heten in de loop der jaren sterker is getrokken. ${ }^{89}$ Waar de hoogleraar geschiedenis Jorissen het rond 1900 nog als een primaire taak zag om eerst de gebeurtenissen van het revolutietijdvak beter te ontsluiten en ook zichzelf van die taak niet vrijstelde, hebben vakhistorici deze visie vanaf de jaren vijftig steeds verder losgelaten. De buiten de wetenschap bloeiende geschiedschrijving hield doorgaans wel vast aan het primaat van beschrijving. De geneigdheid van de jaren zeventig en tachtig om geschiedenis te spiegelen aan de sociale wetenschappen lijkt evenwel gepaard te zijn gegaan met een bij vakhistorici gevoelde noodzaak om meer terughoudendheid te betrachten ten aanzien van werk dat geschreven was door auteurs zonder opleiding tot historicus.

Deze reflex werkt door tot aan de dag van vandaag. Menig vakhistoricus reageert ook nu schamper wanneer lokaalhistorische tijdschriften ter sprake komen, terwijl daar in de loop van de tijd toch de nodige kwalitatief goede stukken zijn verschenen. Ook als een artikel minder goed aansluit bij de doelstellingen van vakhistorici, kan het hen nog altijd op het spoor zetten van bijvoorbeeld een nog onbekende eigentijdse afbeelding of een onvermoed egodocument. Misschien

89 Een recente studie in een heel ander domein waarin dit potentieel nu juist wel wordt benut is Tessel Pollmann, Liever kleine baas dan grote knecht. De Nederlandse middenstand 1920-1970 (Amsterdam 2016). Pollmann baseerde zich voor een groot deel op artikelen in lokaalhistorische tijdschriften en ontving daarvoor veel medewerking van lokaalhistorische verenigingen. nog wel een hogere drempel dan hun eigen elitaire houding vormt voor vakhistorici daarbij de toegankelijkheid van lokaalhistorische bijdragen. Deze staan verspreid in tal van tijdschriften die niet zijn gedigitaliseerd of online minder makkelijk kunnen worden gevonden. Zelfs de titels op het spoor komen kan problematisch zijn. Voor dit artikel is PiCarta doorzocht aan de hand van een groot aantal tref- en titelwoorden gerelateerd aan het revolutietijdvak. Bijdragen die langs deze weg niet konden worden gevonden, zijn alleen in overweging genomen wanneer ze min of meer toevallig werden aangetroffen. ${ }^{90}$ De kwaliteit van niet in PiCarta opgenomen artikelen bleek niet merkbaar minder dan die van vergelijkbare artikelen die daar wel te vinden waren. Dit doet vermoeden dat er ook bruikbare lokaalhistorische studies onder de radar zijn gebleven.

Een desideratum voor de toekomst lijkt me daarom dat lokaal- en regionaalhistorische verenigingen onder professionele begeleiding gaan samenwerken aan een online forum waar hun publicaties fulltekst kunnen worden geraadpleegd en doorzocht. Bij het opzetten hiervan kan het enthousiasme bij de verenigingen zelf van grote waarde zijn.
90 Dit geldt bijvoorbeeld voor artikelen in het Hilversumse lokaalhistorische tijdschrift Eigen Perk, die niet in PiCarta te vinden zijn, of voor artikelen die daar wel te vinden zijn maar waarvan de titels weinig concrete aanknopingspunten bieden, zoals J.B. Schepers, 'Een Hollandsche stad in een roerig tijdvak', De Tijdspiegel 1 (1900) 90-116 (over de patriottentijd in Haarlem). 


\section{Over de auteur}

Dr. Joris Oddens is postdoctoraal onderzoeker bij het Instituut voor Geschiedenis van de Universiteit Leiden. Hij heeft vooral gepubliceerd over het Nederlandse revolutietijdvak en houdt zich momenteel onder meer bezig met lokale geschiedenis en de geschiedenis van verzoekschriften en petities in de decennia rond 1800 .

E-mail: j.oddens@hum.leidenuniv.nl 
